\title{
Keterlihatan Institusi di Alam Maya: Analisis Perbandingan Strategi Komunikasi Laman Sesawang Universiti Penyelidikan Malaysia
}

\author{
MUHAMMAD ZAIAMRI ZAINAL ABIDIN \\ AMIRA FIRDAUS \\ MD AZALANSHAH MD SYED \\ Universiti Malaya
}

\begin{abstract}
ABSTRAK
Keterlihatan laman sesawang semakin menjadi elemen penting untuk mempromosi institusi bagi universiti terbaik dunia. Laman sesawang rasmi universiti bertindak sebagai medium utama untuk mempromosi reputasi dan imej serta menjadi platform publisiti untuk aktiviti dan pencapaian universiti. Laman sesawang memainkan peranan penting dalam mempertingkatkan keterlihatan institusi di peringkat lokal dan juga global, selaras dengan hasrat nasional untuk mengantarabangsakan pendidikan tinggi, contohnya pembangunan hab pendidikan tinggi serantau dan global. Komunikasi laman sesawang memainkan peranan yang penting sebagai tapak perhubungan pertama serta sumber maklumat utama bagi khalayak. Kajian ini meneliti penggunaan laman sesawang secara strategik oleh tiga universiti penyelidikan di Malaysia. Kajian ini juga mengkaji strategi komunikasi laman sesawang bagi setiap universiti menerusi analisis kandungan kualitatif dan pemerhatian secara dalam talian terhadap laman sesawang universiti berkaitan. Ini meliputi analisis secara mendalam terhadap kandungan laman sesawang, reka bentuk dan elemen-elemen lain yang menyumbang kepada keterlihatan universiti melalui komunikasi laman sesawang ketiga-tiga institusi ini. Dapatan kajian mendapati kandungan (content) dan kebolehgunaan (usability) dalam reka bentuk laman sesawang serta komunikasi dialogic (dialogic communication) telah digunakan sebagai strategi keterlihatan laman sesawang. Penekanan komunikasi laman sesawang terhadap ketiga-tiga elemen ini dilihat sebagai strategi utama bagi ketiga-tiga institusi yang dikaji di mana laman sesawang setiap universiti memperlihatkan penggunaan komunikasi yang strategik.
\end{abstract}

Kata kunci: Keterlihatan laman sesawang, laman sesawang rasmi, kandungan, kebolehgunaan, komunikasi dialogik.

\section{Institutional Visibility in Virtual Space: A Comparative Study of Analysis of Website Communication Strategies of Malaysian Research Universities Websites}

\begin{abstract}
Web visibility is increasingly becoming an essential element of institutional promotion for top-ranked universities. A university's official website is a central medium to promote its reputation and image, as well as being a dedicated platform for publicizing university activities and achievements. Institutional websites serve to enhance institutional visibility locally as well as globally, in line with national efforts towards the internationalization of higher education, for example, the establishment of regional and global education hubs. Website communication in the form of high quality attractive, appealing webpages plays an important role as the first point of contact and main reference for the universities' audiences.
\end{abstract}


This study examines three Malaysian research universities' strategic use of their respective institutional websites. The study examines the website communication strategy of each university via qualitative content analysis and online observation of their websites and offers a comprehensive analysis of web content, web design and other elements that contribute to the university's visibility via website communication at these institutions. Study findings suggest that content and usability in website design, as well as dialogic communication, are employed as web visibility strategies. Website communication emphasis of these three elements appears to be the main strategy of all three institutions under study, wherein the strategic use of communication is evident in each university's website.

Keywords: Web visibility, official website, content, usability, dialogic communication.

\section{PENGENALAN}

\section{Keterlihatan Laman Sesawang dan Kepentingannya ke Arah World-Class University}

Wujud kesedaran terhadap kepentingan keterlihatan laman sesawang bagi world class university sebagai kaedah untuk mempromosi dan memastikan keterlihatan institusi terus berlaku di peringkat tempatan dan antarabangsa (Weideman, 2009). Ini kerana laman sesawang merupakan medium utama bagi universiti memaparkan maklumat secara terperinci kepada khalayak umum. Laman sesawang ini juga berfungsi sebagai suatu bentuk komunikasi bersifat kandungan yang berhubung dengan pengguna menerusi paparan ilustrasi dan teks, penyaluran maklumat serta komunikasi. Sebagai contoh, laman sesawang bertindak mewakili institusi dengan memaparkan perkembangan terkini berkaitan berita akademik, kursus yang ditawarkan, kehidupan pelajar, dan maklumat lain yang diperlukan (Suksida \& Santiworarak, 2017).

Terdapat kepentingan di sebalik penggunaan laman sesawang terutama dalam mempengaruhi persepsi umum mengenai imej dan reputasi sesebuah universiti (Lee \& Park, 2012). Maka penting untuk mengoptimumkan penggunaan laman sesawang secara strategik bagi memastikan keterlihatan laman sesawang atau web presence yang mana turut membantu institusi terus relevan dalam persaingan global yang berlaku. Kepentingan ini juga diakui oleh Thelwall (2002) yang berpendapat bahawa menganalisis impak laman sesawang adalah penting seperti menilai impak penyelidikan saintifik menerusi bilangan sitasi yang menjadi ukuran kepada kualiti akademik yang dimiliki, meskipun terdapat sedikit perbezaan seperti dinyatakan oleh $\mathrm{R}$. Jeyshankar dan B. R. Babu. (2009).

Tambahan pula, menurut McNutt dan Marchildon (2009) keterlihatan laman sesawang menjadi fokus yang perlu diberi perhatian bagi universiti ke arah membangunkan hab pendidikan global dan pengantarabangsaan institusi. Untuk itu, kita dapat melihat apabila world class university turut tidak terkecuali mengoptimumkan penggunaan laman sesawang secara strategik sebagai usaha untuk menguasai pasaran pendidikan global. Bahkan menerusi penemuan kajian lepas juga mendapati terdapat hubung kait antara kualiti universiti dalam mempengaruhi keterlihatan laman sesawang bagi sesebuah institusi. Lee dan Park (2012) juga mengakui kebanyakan world class university mempunyai prestasi yang cemerlang dalam aspek keterlihatan laman sesawang.

Sebagai contoh seperti Harvard University, Stanford University, Massachusetts Institute of Technology, University of Washington, University of California Berkeley, University of Michigan dan University Oxford yang berada dalam senarai 10 universiti terbaik dunia turut menduduki 
kedudukan teratas dalam web ranking (Webometric, 2020). Begitu juga dalam konteks Malaysia apabila kebanyakan universiti yang menduduki kedudukan teratas dalam sistem ranking dunia turut mengungguli senarai tertinggi dalam web ranking berbanding institusi pendidikan yang lain di negara tersebut. Jadual 1 menyenaraikan kedudukan bagi lima universiti terbaik di Malaysia yang meliputi senarai ranking di Malaysia, ranking Asia, ranking dunia dan ranking laman sesawang:

Jadual 1: Senarai Ranking Malaysia, Asia, World Ranking dan Kedudukan Web Ranking bagi Universiti di Malaysia

\begin{tabular}{|c|c|c|c|c|c|}
\hline \multicolumn{2}{|c|}{ Senarai Universiti } & \multirow{3}{*}{$\begin{array}{c}\text { Ranking Malaysia } \\
1\end{array}$} & \multirow{3}{*}{$\begin{array}{c}\text { Ranking Asia } \\
18\end{array}$} & \multirow{3}{*}{$\begin{array}{c}\text { World Ranking } \\
70\end{array}$} & \multirow{3}{*}{$\begin{array}{c}\text { Kedudukan Web } \\
\begin{array}{c}\text { Ranking di Malaysia } \\
\text { (Webometrics) } 2020\end{array} \\
1\end{array}$} \\
\hline & & & & & \\
\hline a) & $\begin{array}{l}\text { UniversitI } \\
\text { Malaya }\end{array}$ & & & & \\
\hline \multirow[t]{3}{*}{ b) } & Universiti & & & & \\
\hline & Teknologi & 5 & 45 & 217 & 2 \\
\hline & Malaysia & & & & \\
\hline \multirow[t]{2}{*}{ c) } & Universiti & & & & \\
\hline & Putra Malaysia & 2 & 33 & 159 & 3 \\
\hline \multirow[t]{2}{*}{ d) } & Universiti Sains & 4 & 36 & 165 & 4 \\
\hline & $\begin{array}{l}\text { Malaysia } \\
\text { Universiti }\end{array}$ & & & & \\
\hline \multirow{2}{*}{ e) } & Kebangsaan & 3 & 34 & 160 & 5 \\
\hline & Malaysia & & & & \\
\hline
\end{tabular}

Sumber: Diubahsuai daripada Laporan Senarai Ranking Web of Universities (Webometric) Julai 2019

Situasi ini telah menggalakkan perkembangan budaya penggunaan laman sesawang sebagai saluran utama untuk meningkatkan reputasi institusi, imej organisasi, dan menyebarkan pengetahuan yang dihasilkan kepada komuniti global bagi institusi pendidikan lain (Masterson 2011). Sehinggakan sistem ranking bagi prestasi secara dalam talian juga telah diperkenalkan bagi mengukur sejauh mana sesebuah institusi pendidikan tinggi dan universiti mendapat perhatian secara keseluruhan menerusi internet (Lee \& Park, 2012). Webometric Ranking of World Universities merupakan sebuah laman sesawang ranking utama dalam bidang pendidikan yang menilai sejauh mana kandungan laman sesawang sesebuah universiti mudah untuk diakses secara dalam talian. Objektif utama web ranking ini diperkenalkan adalah untuk menyokong konsep akses terbuka (open access) dan pemindahan ilmu pengetahuan daripada institusi pendidikan kepada masyarakat umum (Lee \& Park, 2012).

Terdapat dua petunjuk utama (indicator) yang digunakan dalam proses penilaian laman sesawang, yang pertama iaitu keterlihatan (visibility) dan yang kedua ialah aktiviti (Suksida \& Santiworarak, 2017). Menerusi sistem web ranking ini mampu menjadi petunjuk kepada senarai universiti yang mendapat perhatian secara dalam talian. Pada masa yang sama sistem ranking ini turut bertindak sebagai cerminan kepada kualiti dan reputasi yang dimiliki serta memberi promosi percuma secara global kepada institusi. Oleh yang demikian, kita dapat melihat pelbagai usaha yang dijalankan oleh universiti masa kini untuk memastikan keterlihatan laman sesawang berlaku. Namun secara spesifiknya apakah bentuk usaha yang dilakukan untuk meningkatkan keterlihatan laman sesawang? 
Salah satunya menurut Alguillo (2009) adalah dengan meningkatkan web audience menerusi pelaksanaan kepelbagaian aktiviti secara dalam talian seperti menerbitkan e-journal, penerbitan raw material, penyebaran informasi mengenai aktiviti semasa, dan menyediakan gudang akses secara terbuka melalui laman sesawang. Begitu juga dengan aktiviti penggunaan media sosial seperti Facebook, Twitter dan Instagram yang turut tidak terkecuali digunakan sebagai medium untuk mendapatkan khalayak secara meluas bagi institusi di samping meningkatkan keterlihatan di pelbagai peringkat (Mirica \& Toma, 2018). Walaupun begitu, timbul persoalan apakah terdapat elemen lain yang berupaya menyumbang kepada keterlihatan laman sesawang? Bagaimana pula dengan peranan kandungan laman sesawang? Adakah kandungan laman sesawang juga mempengaruhi keterlihatan laman sesawang? Stolz et al. (2005) menjelaskan aspek kandungan boleh digunakan sebagai ukuran utama dalam menganalisis sesebuah laman sesawang. Untuk memahami dengan lebih lanjut mengenai peranan kandungan dalam mempengaruhi keterlihatan laman sesawang bagi universiti, kajian ini memfokuskan penyelidikan terhadap kandungan laman sesawang yang diguna pakai terutama oleh world class university di Malaysia. Maka sebelum membincangkan dengan lebih lanjut lagi, kita akan mendalami komunikasi laman sesawang dari perspektif kerangka teori dan konsep.

\section{Komunikasi Laman sesawang, Positive Response Action dan Pembentukan Kandungan}

Kandungan laman sesawang merupakan satu bentuk strategi komunikasi pemasaran organisasi (Sharp, 2001). Kandungan laman sesawang ini bertindak sebagai komunikasi yang menyampaikan pelbagai mesej retorik (seni pemujukan) secara berkesan, sebagai jalinan interaksi bersama khalayak atau pengunjung laman sesawang dan pada masa yang sama turut memastikan keterlihatan laman sesawang berlaku kepada organisasi (Bordbar, 2016). Keberkesanan komunikasi laman sesawang ini amat bergantung kepada kualiti penghasilan sesebuah kandungan web. Kandungan web ini memainkan peranan penting kerana bertindak sebagai frontline yang boleh mempengaruhi proses kognitif individu ketika melayari laman sesawang. Maka menjadi keperluan kepada organisasi menghasilkan kandungan laman sesawang yang efektif agar dapat menyampaikan mesej organisasi secara yang jelas dan berkesan serta meningkatkan kadar kunjungan web (Sharp, 2001).

Menurut Sharp (2001), keberkesanan penyampaian komunikasi menerusi kandungan laman sesawang ini juga mampu mewujudkan kesan positive response action (PRA) kepada pengguna. Ini menjadi objektif utama kepada komunikasi laman sesawang untuk mencapai tindak balas positif daripada pengguna laman sesawang. Positive response action ini memperlihatkan bagaimana kandungan laman sesawang berupaya memberi pengalaman positif kepada pengguna sehingga boleh mempengaruhi persepsi dan perilaku mereka ketika melayari laman sesawang. Sebagai contohnya, pengguna akan kekal menggunakan laman sesawang untuk tempoh yang optimum, memuat turun kandungan, berkongsi kandungan kepada orang lain, membeli item, melanggan untuk maklumat lanjut, atau kembali semula ke laman sesawang di masa akan datang (Owoyele, 2017). Selain dapat memastikan penyaluran informasi secara berkesan, positive response action juga boleh menyumbang berlakunya kepuasan kendiri kepada pengguna laman sesawang. Oleh itu, penting untuk organisasi memberi fokus terhadap penghasilan sesebuah kandungan laman sesawang kerana boleh mempengaruhi proses penggunaan dan penerimaan informasi oleh pengguna laman sesawang. 
Secara amnya, terdapat tiga dimensi komunikasi yang dicadang bagi mewujudkan sebaran komunikasi laman sesawang secara berkesan merangkumi kandungan (content), kebolehgunaan (usability) dan mewujudkan komunikasi dialogic (Sharp, 2001). Ketiga-tiga dimensi ini dirangka bagi membentuk kandungan laman sesawang yang efektif terutama untuk memastikan mesej organisasi dapat disalurkan secara strategik kepada pengguna laman sesawang. Cormier (1999) dan Owoyele (2017) turut memperincikan idea lanjutan mengenai dimensi komunikasi laman sesawang ini dengan memecahkan ketiga idea asal kepada lima dimensi dalam menghasilkan kandungan laman sesawang. Bagi mereka aspek daya tarikan menerusi pengaplikasian lima dimensi berikut memainkan peranan tersendiri untuk merangka kandungan laman sesawang yang efektif. Ini boleh dirujuk menerusi Rajah 1:

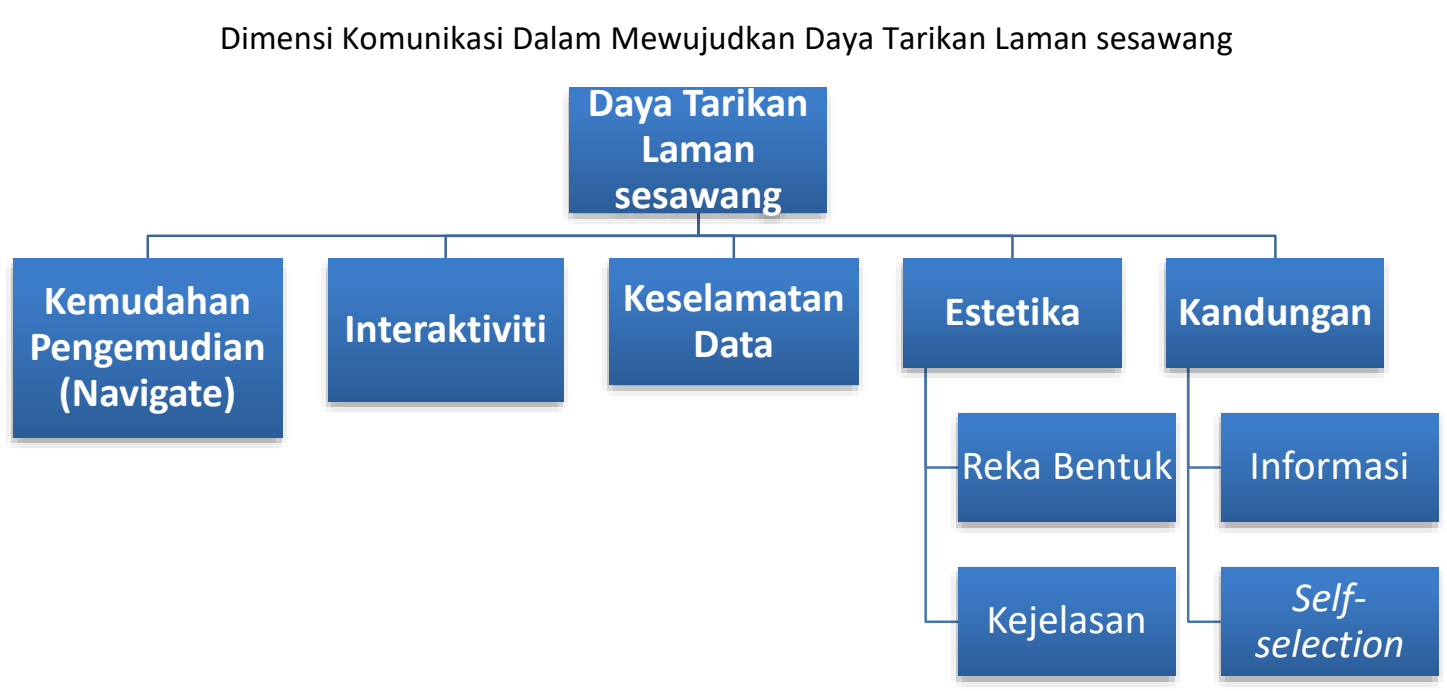

Rajah 1: Diadaptasi daripada konsep web component oleh Cormier (1999) dan Owoyele (2016)

Berdasarkan Rajah 1, terdapat lima dimensi komunikasi laman sesawang yang diperinci oleh Cormier (1999) dan Owoyele (2017) sebagai fokus utama dalam penghasilan sesebuah kandungan laman sesawang. Kelima-lima dimensi ini menjadi petunjuk (indicator) untuk memastikan kandungan laman sesawang itu mempunyai daya tarikan untuk mempengaruhi para pengguna. Bagi dimensi pertama iaitu kemudahan pengemudian merupakan salah satu dimensi penting yang perlu dititikberatkan dalam menghasilkan sesebuah kandungan laman sesawang. Menurut Sharp (2001), keberkesanan komunikasi dan tarikan penggunaan amat bergantung kepada kepuasan kendiri yang dirasai oleh pengguna laman sesawang. Semakin mudah proses pengemudian untuk mendapatkan maklumat dan berkomunikasi dilakukan, semakin mudah untuk individu tertarik dengan kandungan laman sesawang yang dipaparkan (Avila, 1997). Oleh itu, kemudahan pengemudian ini penting untuk memastikan kelancaran proses penyaluran informasi dan komunikasi kepada pengguna serta bertindak sebagai daya tarikan kepada mereka untuk terus melayari laman sesawang.

Begitu juga dengan dimensi kedua iaitu interaktiviti yang berperanan mewujudkan hubungan dialogic antara organisasi dan pengguna laman sesawang (Wirtz \& Zimbres, 2018). Interaktiviti ini merupakan dimensi laman sesawang yang mencipta ikatan emosi bersama 
pengguna yang mana diperlukan oleh setiap jenama atau perkhidmatan (Seltzer \& Mitrook, 2007). Dimensi interaktiviti ini juga memberi ruang tersendiri kepada pengguna untuk berinteraksi bersama organisasi melalui dua cara iaitu interaksi dengan medium dan interaksi melalui medium. Aoki (2000) menjelaskan interaksi dengan medium ini merujuk kepada bagaimana pengguna berinteraksi secara terus dengan kandungan laman sesawang menerusi carian (pilihan sendiri) dan perolehan maklumat sedia ada dalam paparan laman sesawang. Berbeza pula dengan interaksi melalui medium apabila pengguna boleh berkomunikasi secara terus dengan organisasi melalui pautan emel, forum diskusi, ruangan chat, web telephone dan video conferencing (Aoki, 2000). Menerusi pengaplikasian interaktiviti laman sesawang ini, organisasi bukan hanya dapat berinteraksi secara terus dengan para pengguna, malahan dapat memperoleh maklum balas daripada mereka. Ini akan memberi kelebihan tersendiri dalam mewujudkan hubungan komunikasi positif bersama pengguna melalui interaksi yang dibina berdasarkan penggunaan laman sesawang. Bahkan, menurut Huertas et al. (2011) dimensi interaktiviti dalam kandungan laman sesawang juga diakui berperanan menyumbang kepada keterlihatan laman sesawang.

Berbeza pula bagi dimensi ketiga iaitu keselamatan data (data security) yang jadi salah satu dimensi penting yang menyumbang kepada penghasilan kandungan laman sesawang yang efektif. Hal ini kerana keselamatan data penting untuk memastikan tidak berlaku sebarang kehilangan, pencurian data dan ralat kepada pengunjung ketika melayari laman sesawang (Owoyele, 2017). Ini akan mengurangkan berlakunya gangguan kepada penyaluran informasi dan komunikasi kepada pengguna laman sesawang. Hal ini disebabkan gangguan bertindak sebagai penghalang yang boleh menganggu-gugat proses interaksi organisasi dan para pengguna serta pada masa yang menjejaskan daya tarikan sesebuah laman sesawang. Malahan, jaminan keselamatan ini akan membuatkan para pengguna merasa lebih selesa dan selamat untuk melayari laman sesawang.

Seterusnya, pembentukan nilai estetika dalam kandungan laman sesawang turut tidak terkecuali menjadi dimensi keempat dalam proses penghasilan laman sesawang. Ini disebabkan reka bentuk dan kandungan laman sesawang memberi nilai estetika atau kesan tertentu kepada pengguna untuk melihat sesuatu maklumat dan mempelajarinya serta bertindak sebagai penilai kepada kredibiliti dan kebolehgunaan sesebuah laman sesawang. Untuk menghasilkan laman sesawang bagi tujuan komunikasi pemasaran, pemilihan kandungan yang sesuai, unsur-unsur visual dan estetika memainkan peranan yang penting bagi memastikan ketepatan penyampaian mesej yang sesuai serta pada masa yang sama mampu mempengaruhi emosi pengguna laman sesawang. Malahan menerusi dapatan kajian lepas turut menemukan kepentingan dimensi estetika dalam reka bentuk laman sesawang sebagai cerminan kepada kredibiliti yang berupaya mempengaruhi penerimaan dan penggunaan laman sesawang. Dengan itu aspek reka bentuk dan kejelasan perlu dititikberatkan dalam penghasilan kandungan laman sesawang kerana boleh mempengaruhi pembentukan nilai estetika bagi sesebuah laman sesawang.

Bagi dimensi yang terakhir iaitu kandungan juga berperanan dalam menyumbang kepada daya tarikan bagi laman sesawang. Hal ini kerana kandungan laman sesawang disifatkan sebagai analogue of books dalam pautan laman sesawang yang menyediakan pelbagai jenis maklumat kepada pengguna laman sesawang. Kandungan laman sesawang juga bertindak sebagai sumber informasi utama yang menjelaskan secara terperinci maklumat mengenai organisasi sama ada 
berkaitan perkhidmatan atau produk (Sharp, 2001). Untuk itu kandungan laman sesawang haruslah bersifat menarik dan relevan dengan membawa informasi sama ada yang ingin disampaikan oleh organisasi atau berdasarkan keperluan pengguna. Pihak organisasi harus memastikan kandungan informasi yang dimuat naik dalam laman sesawang mampu diakses secara mudah dan pantas berdasarkan penyediaan maklumat sedia ada serta mengikut pilihan pengguna. Oleh yang demikian, Cormier (1999) dan Owoyele (2017) memberi fokus terhadap dua elemen penting yang berupaya mempengaruhi keberkesanan penyampaian komunikasi dalam kandungan iaitu penyediaan informasi dan self-selection information yang bertindak sebagai daya tarikan kepada penggunaan laman sesawang.

Berdasarkan penjelasan mengenai kerangka dimensi komunikasi laman sesawang ini telah memperincikan bagaimana daya tarikan kandungan laman sesawang boleh dibentuk bagi membantu organisasi untuk menyebarkan komunikasi secara berkesan dan berinteraksi dalam talian bersama pengguna. Namun perlu difahami juga menerusi penghasilan kandungan laman sesawang yang efektif ini boleh menyumbang kepada keterlihatan laman sesawang sebagai usaha untuk mengukuhkan jenama dan mempromosi organisasi. Untuk itu, perlu diberi penekanan terhadap pengaplikasian dimensi tersebut bagi mewujudkan daya tarikan kepada kandungan laman sesawang. Pada sub-topik seterusnya, kita akan membincangkan secara lanjut rangkuman kajian lepas bagi mendalami topik keterlihatan laman sesawang dan mengenal pasti apakah fokus yang sering diberi perhatian dalam bidang kajian ini daripada perspektif universiti.

\section{ULASAN KAJIAN LEPAS}

Dalam membincangkan mengenai penggunaan laman sesawang dan kepentingan keterlihatan laman sesawang ke arah world-class university, tidak boleh dinafikan terdapat kepelbagaian kajian lepas yang memfokuskan perbincangan terhadap topik dan skop kajian ini. Berdasarkan proses pembacaan dan analisis yang dijalankan, pengkaji mendapati terdapat beberapa tema yang sering difokuskan oleh kajian terdahulu yang merangkumi aspek reka bentuk laman sesawang dalam mempengaruhi keterlihatan laman sesawang, kandungan pautan laman sesawang antarabangsa dan petunjuk (indicator) dalam Webometric.

Menyentuh tema pertama iaitu aspek reka bentuk laman sesawang, terdapat beberapa pengkaji seperti Qiu, M. (2020), Ng (2020), Ashraf et al. (2019), Conte et al. (2007), Leavitt dan Shneiderman (2006), Petricek et al. (2006), Tarafdar (2005), Palmer (2002), Chevalier et al. (2003), serta Zhang et al. (2000) yang memfokus penyelidikan mengenai keterlihatan laman sesawang daripada perspektif reka bentuk halaman sesawang. Kebanyakan daripada kajian berikut membincangkan elemen usability dalam reka bentuk laman sesawang terutama dalam mempengaruhi keterlihatan laman sesawang kepada universiti. Terdapat beberapa perkara yang dikaji menerusi elemen usability yang berkaitan tentang proses reka bentuk (design process), seni bina (architecture) kandungan laman sesawang, perkakasan/perisian (hardware/software), pemanduan arah laman sesawang (web navigation), laman utama (homepage), kredibiliti (credibility), bantuan, carian, dan toleransi kesilapan (help, search and error tolerance), serta kandungan laman sesawang yang menyumbang kepada keterlihatan laman sesawang bagi institusi. Menerusi kajian ini, kita dapat memahami bagaimana aspek reka bentuk juga memainkan peranan utama dalam meningkat dan memastikan keterlihatan laman sesawang 
berlaku berdasarkan penekanan terhadap 10 kriteria utama yang menyumbang kepada web usability bagi laman sesawang sesebuah institusi.

Berbeza pula dengan tema kedua yang memfokuskan penyelidikan dari perspektif kandungan pautan laman sesawang antarabangsa dalam mengkaji keterlihatan laman sesawang. Kajian dalam skop ini lebih tertumpu membincangkan kandungan pautan laman sesawang antarabangsa dengan menghubungkaitkan teori sistem dunia (world-system theory) oleh Wallerstein (1974) dalam mempengaruhi web presence sesebuah institusi pendidikan tinggi. Kebanyakan daripada kajian ini mengadaptasi konsep seperti negara-negara teras (core countries), negara separa pinggiran (semi-periphery countries), dan negara-negara pinggiran (periphery countries) dalam menjelaskan pembentukan kandungan dalam pautan (link) laman sesawang antarabangsa. Dengan itu terbentuklah pengkategorian mengikut kandungan seperti teras (core) yang merujuk universiti di seluruh Amerika Syarikat, separa pinggiran (semi-periphery countries) iaitu universiti dalam kelompok negara United Kingdom dan Australia serta pinggiran (periphery) yang merangkumi universiti di negara Asia dan Eropah Barat di Benua Eropah (Lee \& Park 2012).

Pengkategorian ini menjelaskan bagaimana peningkatan pemusatan dan kepelbagaian dalam keterlihatan laman sesawang berlaku dengan memperlihatkan negara-negara teras terutama English-Speaking Countries yang terdiri daripada negara-negara teras lebih mendominasi keterlihatan laman sesawang berbanding negara Non-English Speaking (Lee \& Park 2012). Walaupun begitu, dominasi ini tidaklah berlaku secara keseluruhan kerana terdapat faktor lain seperti keterdekatan geografi, penggunaan Bahasa Inggeris dan kerjasama akademik serantau yang turut mempengaruhi keterlihatan laman sesawang di negara separa pinggiran dan pinggiran. Untuk itu, kita dapat melihat bagaimana elemen lokasi geografi dan penggunaan bahasa menjadi salah satu petunjuk penting kepada keterlihatan laman sesawang bagi universiti. Kajian dalam konteks ini telah menarik pengkaji seperti Fatta et al. (2016), Masterson (2011), Lee dan Park (2011), Abedin dan Sohrabi (2009), Matei (2006), Park dan Thelwall (2006), Barnett dan Park (2005) serta Monge et al. (2003), untuk membincangkan aspek kandungan laman sesawang dari perspektif antarabangsa untuk menjelaskan peranannya terhadap keterlihatan laman sesawang.

Manakala bagi tema kajian terakhir pula iaitu petunjuk (indicator) kepada Webometric turut tidak terkecuali difokuskan oleh pengkaji terdahulu bagi membincangkan secara terperinci mengenai keterlihatan laman sesawang dan kepentingannya terhadap universiti. Sering kali kajian dalam konteks ini dilakukan untuk mengkaji petunjuk utama yang boleh menyumbang kepada peningkatan prestasi sesebuah laman sesawang kepada universiti. Kebanyakan daripada kajian ini mengetengahkan idea mengenai pembangunan petunjuk yang berfungsi untuk mengukur aktiviti dan keterlihatan laman sesawang sesebuah universiti.

Terdapat tiga kumpulan petunjuk yang dikenalpasti dan dibangunkan oleh para pengkaji merangkumi aktiviti (dokumen yang disimpan oleh pengarang, subjek, institusi), penggunaan (bilangan kunjungan, pelawat dan muat turun), dan visibility (citations dan pautan laman sesawang). Menerusi penemuan petunjuk ini tidak hanya membantu universiti dari segi menyumbang kepada peningkatan dalam sistem ranking Webometric sahaja, malahan bertindak sebagai proses penilaian semasa dan penambahbaikan ke arah keterlihatan laman sesawang di masa hadapan. Ini telah menarik perhatian pengkaji seperti Acosta-Vargas et al. (2020), 
Shahruddin et al. (2019), Jeyshankar, (2019), Aguillo (2010), Kim dan Kim (2008), Barjak et al. (2007), Meho dan Yang (2007), serta Xia dan Sun (2006) untuk mengkaji petunjuk dalam Webometric sebagai usaha untuk memahami elemen keterlihatan laman sesawang dengan lebih mendalam.

Menerusi penelitian terhadap pola kajian lepas ini dapat disimpulkan bahawa empat tema utama yang dikenalpasti sering difokuskan oleh pengkaji bagi membincangkan elemen keterlihatan laman sesawang daripada pelbagai perspektif. Bermula daripada kajian yang memfokuskan peranan reka bentuk laman sesawang, kandungan pautan laman sesawang dalam konteks antarabangsa sehinggalah petunjuk kepada Webometric yang berperanan dalam memberi pemahaman berkenaan idea keterlihatan laman sesawang dan sumbangannya ke arah universiti. Namun terdapat jurang kajian yang dikenalpasti terutama dalam membincangkan komunikasi laman sesawang daripada perspektif bidang perhubungan awam. Maka untuk memahami dengan lebih lanjut penggunaan laman sesawang secara strategik sebagai usaha untuk meningkat dan memastikan keterlihatan laman sesawang berlaku, kajian ini akan menyelidik apakah strategi komunikasi laman sesawang yang diguna pakai yang menyumbang kepada keterlihatan laman sesawang universiti? Ini meliputi penelitian terhadap kandungan laman sesawang yang diguna pakai sebagai usaha untuk meningkat dan memastikan keterlihatan universiti berlaku secara dalam talian. Di akhir kajian ini, kita akan memahami bagaimana dimensi laman sesawang yang dibentuk menerusi strategi komunikasi ini menyumbang ke arah keterlihatan laman sesawang.

\section{PROSES KAJIAN}

Pendekatan kaedah kualitatif telah dipilih selaras dengan fokus kajian yang ingin meneroka strategi komunikasi laman sesawang yang digunakan sebagai usaha untuk memastikan keterlihatan laman sesawang berlaku kepada universiti. Pendekatan ini secara khususnya melibatkan dua proses aturcara kutipan data merangkumi analisis kandungan laman sesawang secara mendalam (online content analysis) dan pemerhatian turut serta dalam mengkaji aktiviti komunikasi laman sesawang universiti. Analisis kandungan secara dalam talian ini merupakan kumpulan daripada teknik penyelidikan yang diguna untuk mengkaji secara terperinci menerusi pengekodan dan interpretasi secara sistematik (Herrring, 2009). Analisis kandungan secara dalam talian ini juga bertindak sebagai suatu bentuk analisis kandungan yang menganalisis komunikasi yang berasaskan internet (McMillan, 2000).

Pemilihan proses analisis kandungan secara mendalam sebagai instrumen kajian ini adalah berperanan untuk membantu penyelidik mengkaji laman sesawang yang digunakan oleh universiti menerusi penelitian secara mendalam terhadap kandungan laman sesawang. Manakala bagi pemerhatian turut serta pula bertindak sebagai data sokongan kepada penyelidik untuk memahami proses komunikasi dari perspektif perangkaan dan pelaksanaannya. Kaedah kajian ini turut digunakan dan dicadang oleh penyelidikan lepas seperti Gomes dan Murphy (2003), Matusitz (2005), serta Yusof et al. (2010) kerana berupaya membantu penyelidik untuk mendalami penggunaan laman sesawang oleh universiti menerusi analisis kandungan dan pemerhatian bagi memahami bagaimana kandungan laman sesawang ini menyumbang kepada keterlihatan laman sesawang. Ini juga diakui oleh Caglar dan Mentes (2012) yang menjelaskan keberkesanan penggunaan kaedah analisis kandungan dan pemerhatian secara mendalam 
terhadap kandungan laman sesawang kerana berupaya membantu penyelidik untuk meneroka dan memperincikan setiap dimensi laman sesawang yang terlibat dalam proses komunikasi laman sesawang.

Bagi mengendalikan kajian, penyelidik telah memilih tiga universiti penyelidikan utama di Malaysia yang melibatkan Universiti Malaya (UM), Universiti Putra Malaysia (UPM) dan Universiti Kebangsaan Malaysia (UKM). Ini selaras dengan peranan universiti penyelidikan Malaysia yang terlibat dalam usaha ke lonjakan global menerusi proses pengantarabangsaan institusi dan pembangunan hab pendidikan global yang telah dan sedang dijalankan oleh institusi berikut. Bahkan, ketiga-tiga universiti tersebut turut berada dalam kedudukan tiga teratas senarai ranking tempatan dan sistem ranking universiti terbaik dunia mengikut QS ranking system. Pemilihan ketiga universiti ini turut tidak terkecuali dipengaruhi oleh kedudukan sistem web ranking iaitu Webometric yang menjelaskan bagaimana UM, UPM dan UKM memberi perhatian yang khusus dalam aspek keterlihatan laman sesawang sebagai langkah untuk mempertingkatkan kualiti institusi ke arah world class university berbanding universiti lain yang terdapat di Malaysia.

Fokus kajian ini tertumpu dalam menganalisis kandungan laman sesawang bagi ketigatiga universiti tersebut. Analisis kandungan dan pemerhatian yang dibuat lebih tertumpu kepada aspek kandungan yang terdapat dalam laman sesawang. Ini bagi mengenal pasti apakah strategi komunikasi yang dirangka dan digunakan menerusi pengimplementasian kandungan laman sesawang yang dibentuk. Kajian ini akan menganalisis dari segi persamaan dan perbezaan penggunaan strategi komunikasi laman sesawang yang digunakan berdasarkan penelitian terhadap kandungan laman sesawang bagi ketiga-tiga universiti tersebut. Kajian ini secara khususnya berlangsung daripada 1 Mei sehingga 31 Ogos 2019, di mana pengkaji membuat analisis kandungan dan pemerhatian terhadap tiga laman sesawang bagi universiti tersebut bagi tempoh masa tiga bulan tersebut. Ini bagi memastikan analisis dan pemerhatian secara konsisten dilakukan dan mahu mengelakkan sebarang perubahan kandungan serta kandungan laman sesawang sepanjang tiga bulan tersebut.

Dapatan kajian ini dianalisis berdasarkan pendekatan interpretasi (interpretation) yang dicadangkan bagi analisis kandungan secara dalam talian daripada perspektif kualitatif. Bagi proses kebolehpercayaan (realibility) dan pengesahan (validation) data, pengkaji menjalankan dua cara iaitu secara dalaman (internal) dan luaran (external). Proses secara dalaman ini melibatkan pengujian data yang dilakukan oleh pengkaji sendiri, di mana analisis data akan dilakukan secara berulang pada tempoh masa yang berbeza. Ini bagi memastikan tema-tema dapatan kajian yang dibentuk mempunyai persamaan walaupun dilakukan bagi tempoh yang berbeza. Manakala bagi proses secara luaran pula, pengkaji akan melakukan pengujian data menerusi individu lain bagi mengukur persamaan daripada segi dapatan kajian yang diperoleh. Pengkaji akan melakukan perbandingan tema-tema yang dibentuk oleh pengkaji dan individu lain bagi menguji persamaan dan kefahaman mengenai data tersebut.

\section{DAPATAN KAJIAN}

Berdasarkan dapatan kajian yang diperoleh terdapat tiga tema utama yang dikenalpasti menjelaskan secara terperinci strategi komunikasi yang diguna pakai oleh UM, UPM, dan UKM menerusi kandungan laman sesawang. Ini meliputi rangkuman tema seperti penekanan terhadap keberkesanan kandungan laman sesawang dalam penyampaian informasi, kelancaran fungsi 
kebolehgunaan laman sesawang dan mewujudkan interaksi menerusi komunikasi dialogic sebagai strategi ke arah keterlihatan laman sesawang. Berikut adalah jadual yang memperincikan dimensi atau sub-tema yang terdapat dalam setiap tema yang dinyatakan:

Jadual 2: Perincian mengenai tema berdasarkan dapatan kajian yang di peroleh

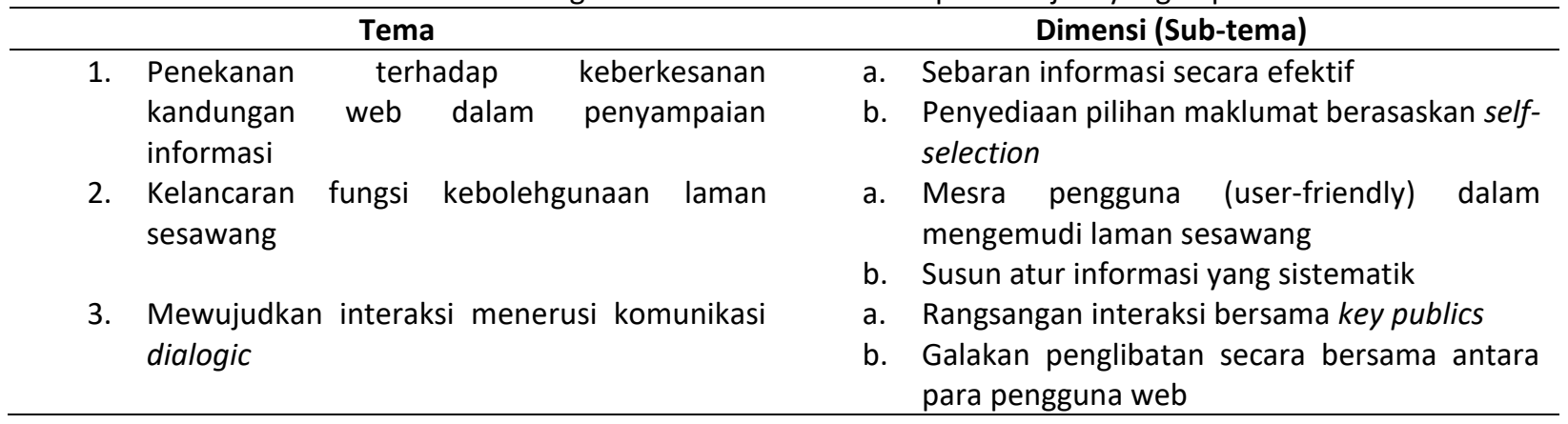

Menyentuh tema pertama iaitu penekanan terhadap keberkesanan kandungan laman sesawang dalam penyampaian informasi, terdapat dua dimensi utama yang difokuskan merangkumi sebaran informasi secara efektif dan penyediaan pilihan maklumat berasaskan selfselection untuk pengguna laman sesawang. Pada peringkat ini, pihak UM, UPM dan UKM memberi fokus kepada penghasilan kandungan laman sesawang yang lebih bersifat informational dan estetika.

Selaras dengan dimensi pertama iaitu sebaran informasi secara efektif, UM, UPM, dan UKM memfokuskan strategi komunikasi dengan merangka kandungan yang berasaskan penyediaan informasi secara strategik. Informasi yang disediakan mencakupi pelbagai segmen pengguna seperti staf, pelajar, bakal pelajar, bekas pelajar (alumni) dan khayalak umum. Jenis kandungan informasi juga mengandungi maklumat berkaitan universiti secara keseluruhan, bidang dan kursus yang ditawarkan, senarai penganjuran aktiviti dan program, penyelidikan universiti serta peluang kerjaya yang ditawarkan. Ini boleh dijelaskan menerusi tangkap layar (screenshot) laman sesawang bagi UM, UPM dan UKM (lihat Rajah 2) yang menyediakan informasi secara strategik berdasarkan segmen pengguna dan jenis informasi:

\section{Laman sesawang UM}

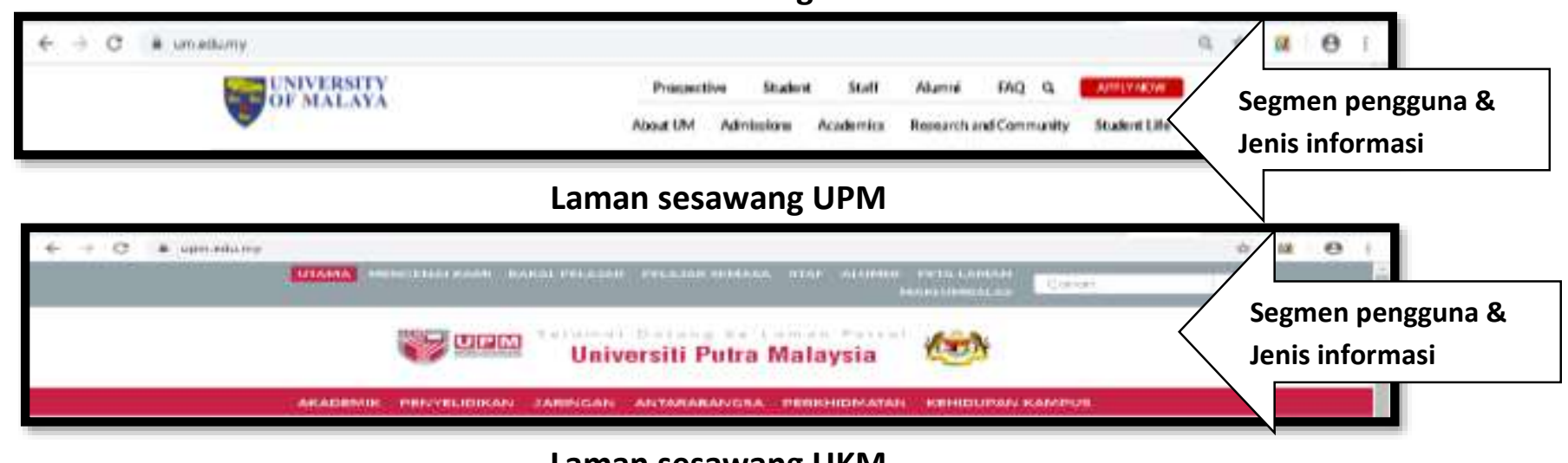

Laman sesawang UKM 


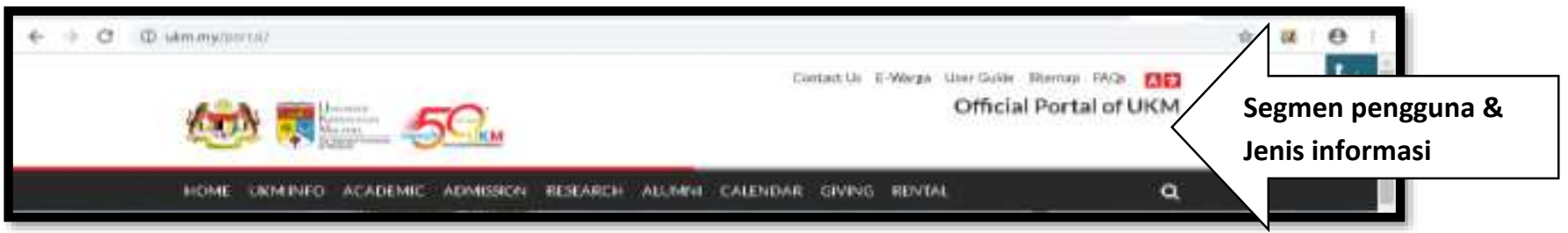

Rajah 2: Portal rasmi universiti (UM, UPM DAN UKM)

Begitu juga dengan penekanan terhadap nilai estetika daripada segi penghasilan kandungan laman sesawang bagi memastikan sebaran komunikasi secara efektif dapat dilakukan oleh universiti tersebut. Nilai estetika ini dibentuk berdasarkan penggunaan kesan grafik dan simbol visual untuk menyokong kandungan teks agar penyampaian komunikasi dapat dilakukan secara berkesan. Ini membantu ketiga-tiga universiti berkenaan untuk menyampaikan mesej secara tepat kepada sasaran pengguna serta mencipta keterhubungan yang kuat dan bersifat emosi. Hal ini menjadikan kandungan laman sesawang bagi ketiga-tiga universiti tersebut dilihat lebih bersifat interaktif, jelas dan mudah untuk difahami oleh pengguna laman sesawang. Ini boleh dijelaskan menerusi paparan kandungan laman sesawang yang digunakan oleh UM, UPM dan UKM (lihat Rajah 3): 


\section{Laman sesawang UM}

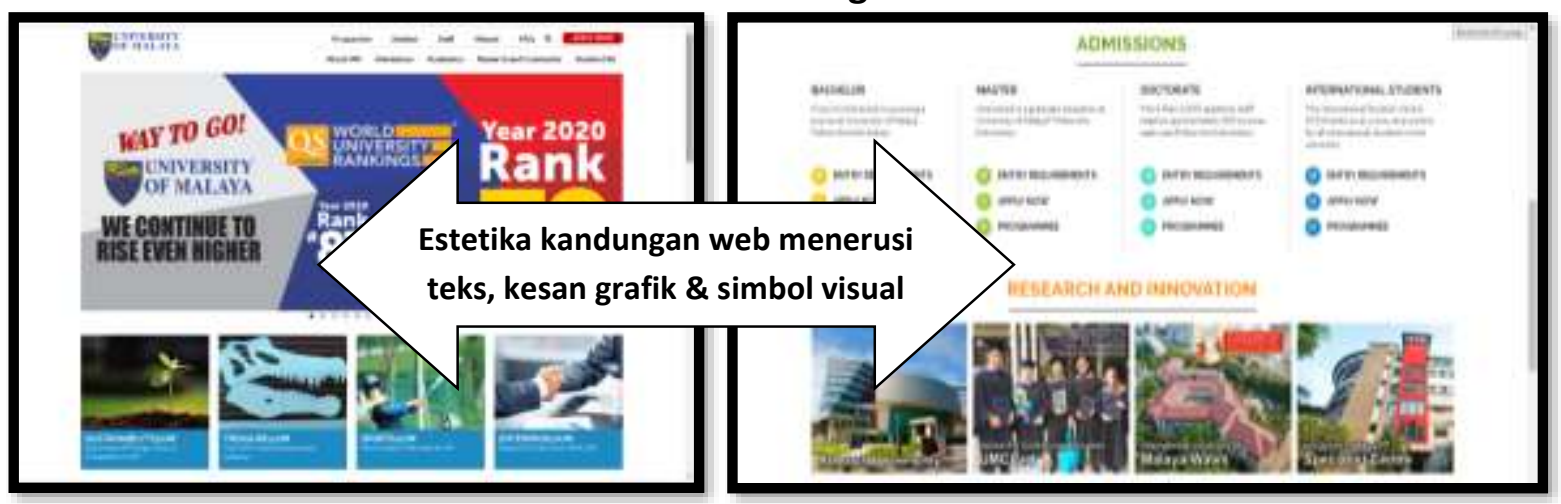

\section{Laman sesawang UPM}

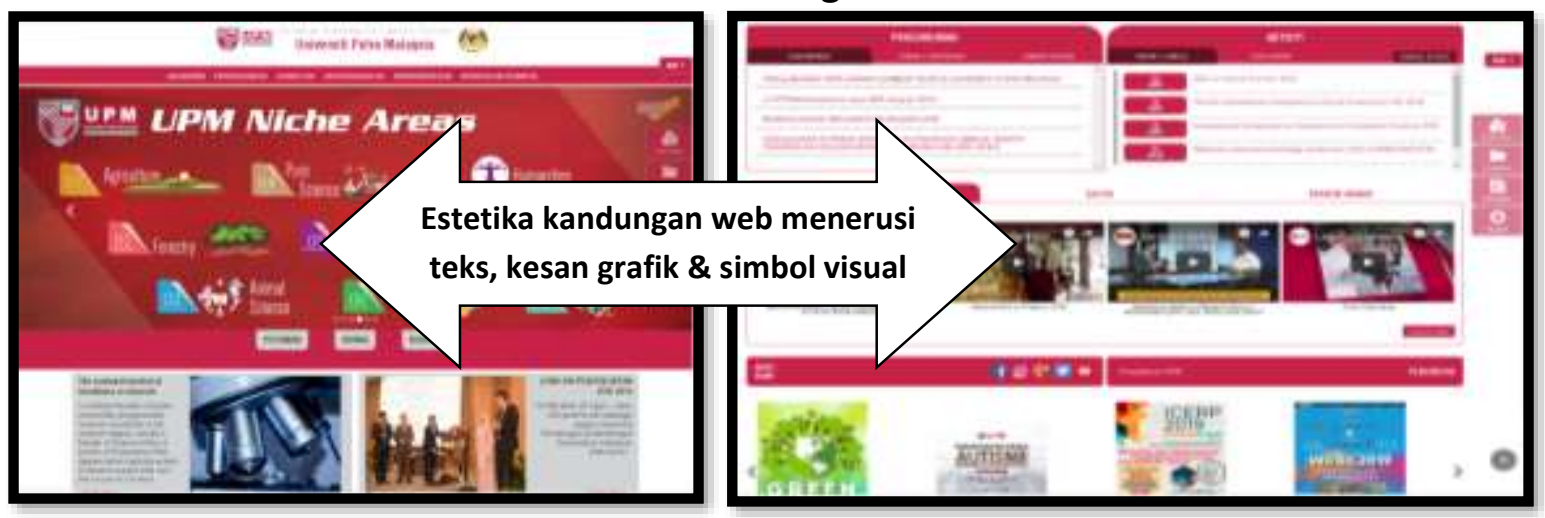

Laman sesawang UKM

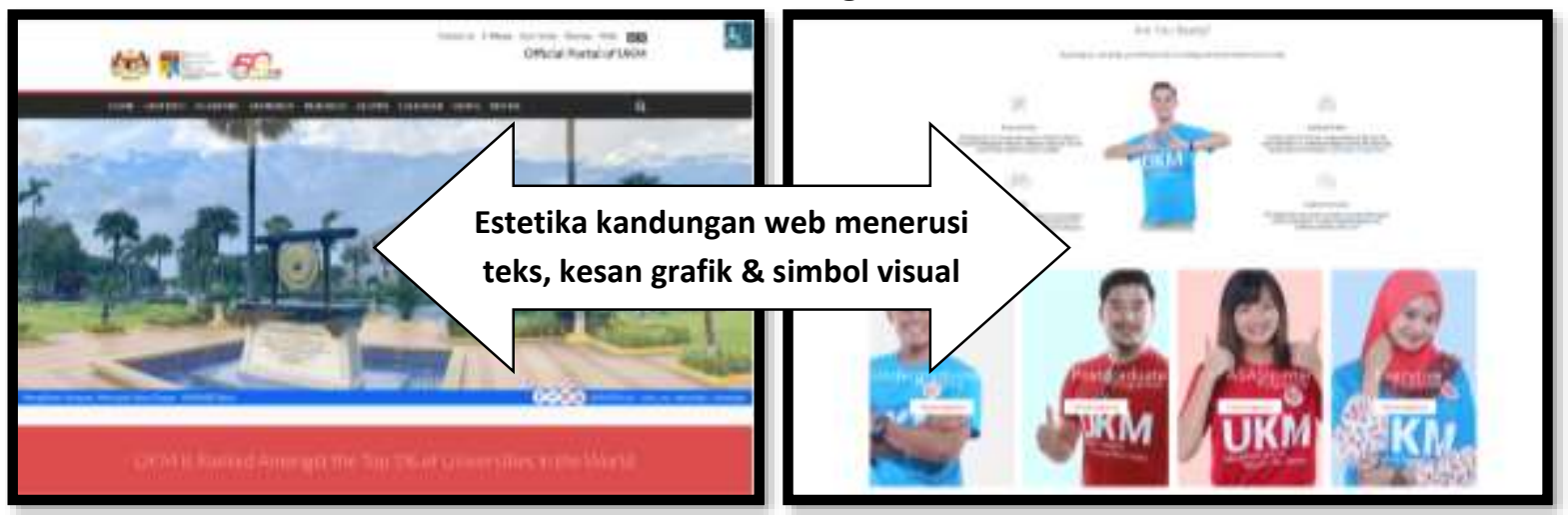

Rajah 3: Nilai estetika portal rasmi universiti (UM, UPM DAN UKM)

Selain daripada memastikan sebaran informasi secara strategik menerusi penyediaan maklumat yang mencakupi pelbagai segmen pengguna, jenis kandungannya dan penekanan nilai estetika, pihak UM, UPM dan UKM turut memfokuskan penyediaan informasi yang berasaskan pilihan penggunaan atau self selection. Pilihan maklumat ini dirangka secara dalam pautan atau inlinks yang memberi kemudahan kepada pengguna untuk mendapatkan maklumat yang diperlukan sahaja. Pengguna hanya perlu memilih informasi yang diinginkan tanpa perlu 
mengakses secara keseluruhan kandungan laman sesawang. Pengaplikasian self selection ini dilakukan bagi memastikan komunikasi laman sesawang dapat disebarkan secara efektif dengan mengelakkan lambakan informasi yang boleh menganggu proses penerimaan kepada pengguna. Hal ini disebabkan penggunaan laman sesawang sering kali dipengaruhi dengan aktiviti pencarian informasi yang berlandaskan keperluan diri dan kemahuan pengguna.

Fungsi self-selection ini turut digunakan menerusi penyediaan kandungan laman sesawang secara dwibahasa bagi ketiga-tiga laman universiti tersebut. Terdapat dua jenis format bahasa yang disediakan yang meliputi penggunaan Bahasa Malaysia dan Inggeris kepada pengguna laman sesawang. Penyediaan dwibahasa dalam format kandungan ini bertindak sebagai strategi komunikasi laman sesawang yang bertujuan untuk memudahkan proses penyebaran dan penerimaan informasi. Ini bagi mewujudkan daya tarikan tersendiri dalam kandungan laman sesawang kerana faktor bahasa memainkan peranan penting dalam mempengaruhi penggunaan sesebuah laman sesawang. Justeru penyediaan informasi mengikut self selection oleh UM, UPM dan UKM ini bertindak untuk memudahkan proses sebaran komunikasi kepada pengguna. Ini boleh diperinci berdasarkan tangkapan skrin bagi ketiga-tiga laman sesawang universiti berikut (lihat Rajah 4):

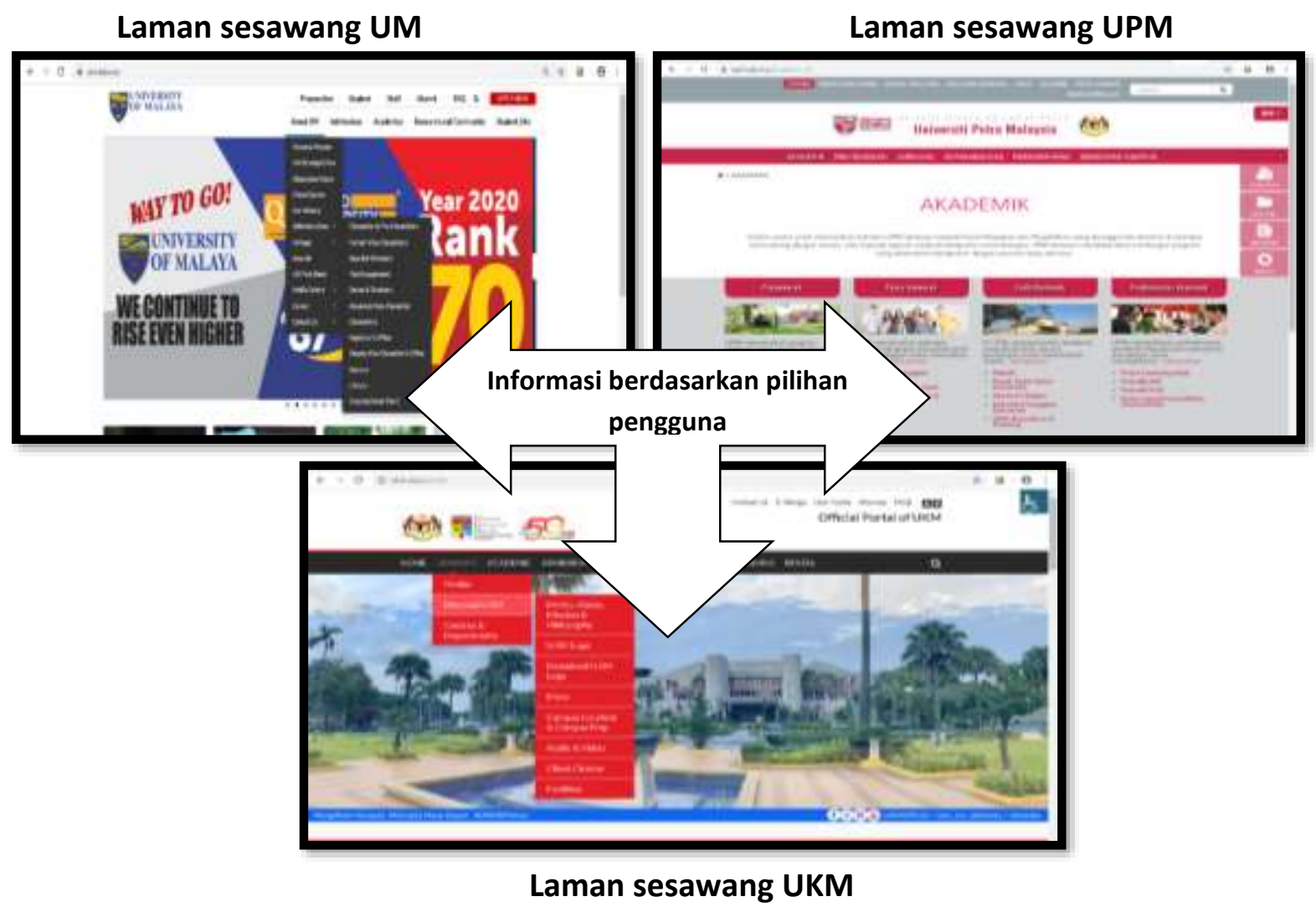

Rajah 4: Fungsi pilihan penggunaan dalam portal rasmi universiti (UM, UPM DAN UKM)

Berlainan pula bagi tema kedua iaitu kelancaran fungsi kebolehgunaan laman sesawang yang bertindak sebagai strategi komunikasi dalam penghasilan kandungan laman sesawang bagi UM, UPM, dan UKM. Tidak dapat dinafikan nilai estetika amat penting dalam penghasilan 
kandungan laman sesawang, namun begitu kefungsian laman sesawang atau web functionality juga memainkan peranan tersendiri untuk memastikan keberkesanan komunikasi laman sesawang. Pada peringkat ini, ketiga-tiga universiti tersebut memfokuskan reka bentuk dalam kandungan bagi meningkatkan fungsi kebolehgunaan dalam laman sesawang.

Terdapat dua dimensi utama yang difokuskan berdasarkan tema ini seperti mesra pengguna (user-friendly) dalam mengemudi laman sesawang dan susun atur informasi yang sistematik diaplikasi dalam kandungan laman sesawang. Kedua aspek ini penting untuk memastikan pengguna dapat merasakan fungsi kebolehgunaan (usability) menerusi web controllability dan web efficiency ketika mengakses kandungan laman sesawang. Web controllability secara khususnya memberi keupayaan kepada pengguna untuk mengawal interaksi ketika mengakses kandungan laman sesawang.

Sebagai contoh para pengguna boleh mengemudi laman sesawang secara mudah dan melakukan aktiviti yang diingini. Ini membolehkan penyebaran komunikasi secara berkesan berlaku apabila para pengguna dapat merasakan kemudahan dan kelancaran dari segi akses maklumat dalam kandungan laman sesawang. Kawalan pengemudian yang lemah akan menganggu fungsi kebolehgunaan dalam sesebuah kandungan laman sesawang. Oleh itu, kawalan secara sendiri yang terdapat pada ketiga-tiga laman sesawang tersebut membuatkan para pengguna dapat menikmati kandungan laman sesawang yang mesra pengguna atau userfriendly.

Selain memastikan kandungan laman sesawang bersifat mesra pengguna, penekanan terhadap susun atur informasi yang sistematik turut diaplikasikan oleh UM, UPM dan UKM untuk meningkat fungsi kebolehupayaan dalam kandungan laman sesawang. Susun atur informasi ini penting bagi kandungan laman sesawang kerana boleh mempengaruhi proses penggunaan dan penerimaan informasi oleh para pengguna. Ini disebabkan keberkesanan penyampaian komunikasi dalam bentuk paparan ini juga bergantung kepada sejauh mana struktur atau susun atur dalam kandungan laman sesawang itu dirangka secara efektif.

Untuk itu, kita dapat melihat bagaimana ketiga-tiga universiti penyelidikan tersebut merangka kandungan laman sesawang yang mempunyai susun atur yang sistematik dan strategik bagi memastikan keberkesanan penyampaian komunikasi kepada pengguna. Susun atur kandungan yang sistematik dan strategik ini berfungsi untuk meningkatkan kecekapan penggunaan terutama untuk pengguna mencapai matlamat ketika melayari laman sesawang dengan cepat tanpa meletakkan banyak usaha kognitif. Ini dapat memberi pengalaman terhadap kecekapan laman sesawang yang tinggi apabila pengguna dapat melakukan aktiviti laman sesawang dengan tempoh masa yang singkat dan efisyen. Hal ini dapat dijelaskan menerusi tangkapan skrin bagi susun atur kandungan laman sesawang bagi UM, UPM dan UKM (lihat Rajah 5): 
Keterlihatan Institusi di Alam Maya: Analisis Perbandingan Strategi Komunikasi Laman sesawang Universiti Penyelidikan Malaysia
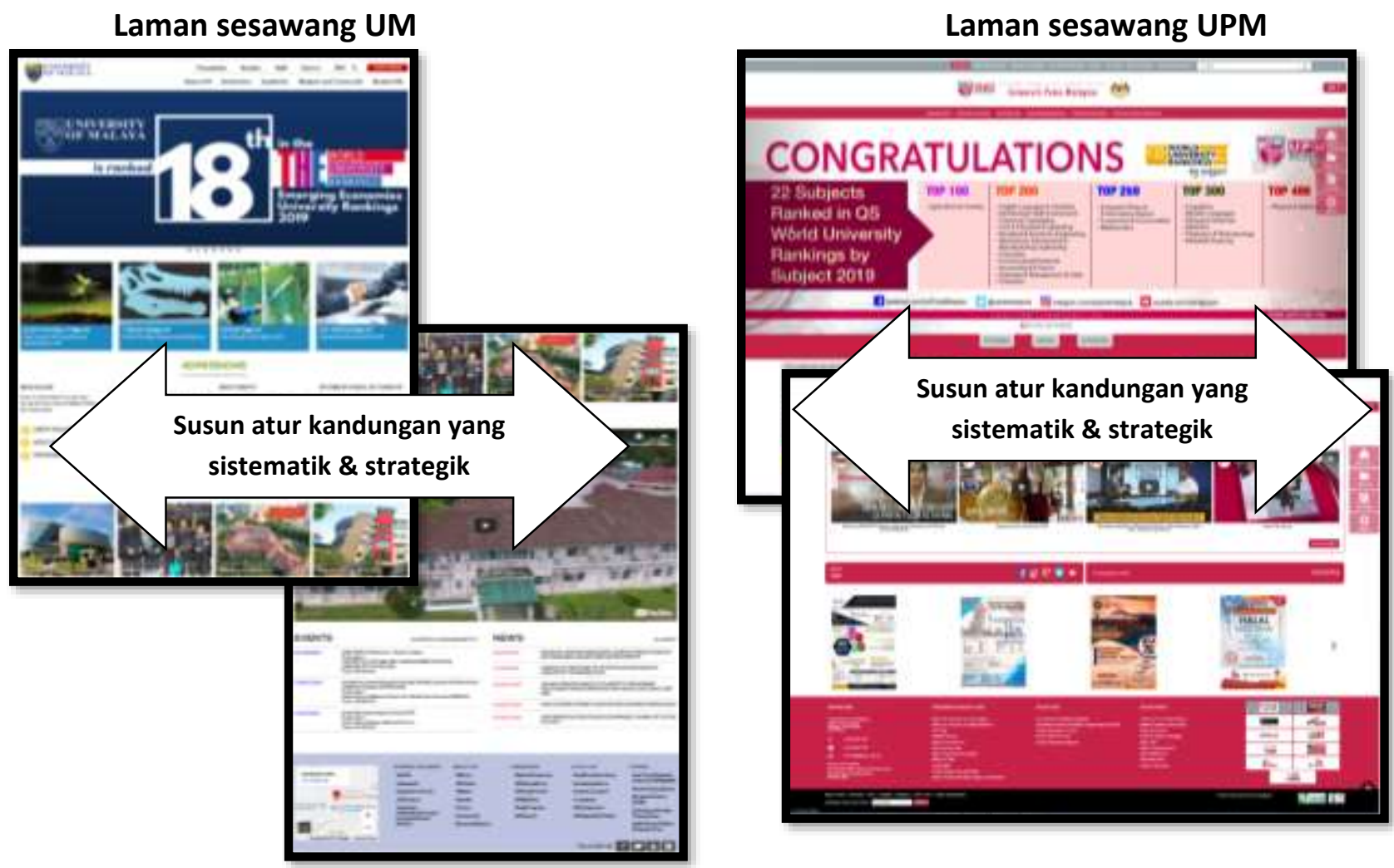

\section{Laman sesawang UKM}

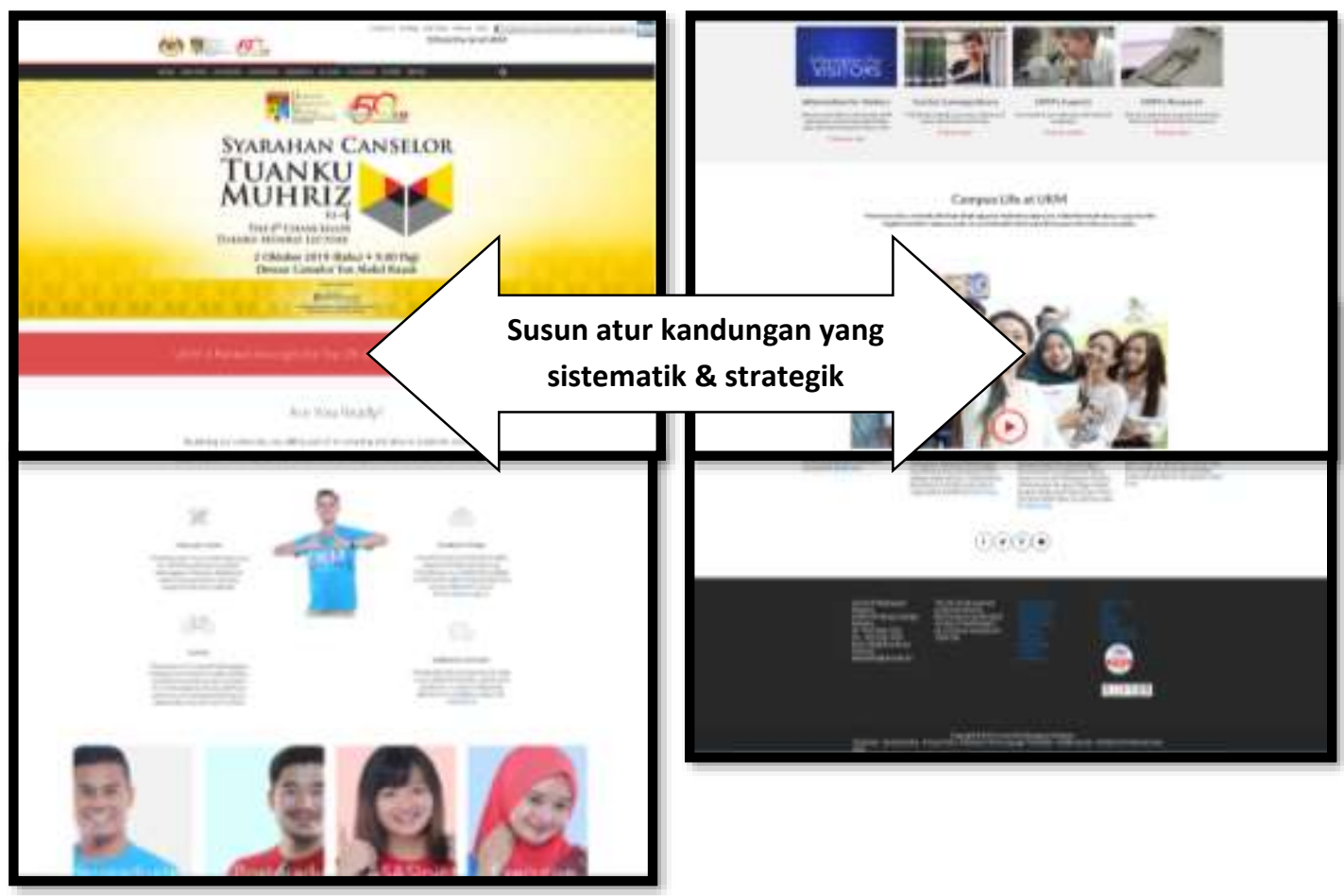

Rajah 5: Susun atur kandungan portal rasmi universiti (UM, UPM DAN UKM) 
Seterusnya pula, bagi tema yang terakhir iaitu mewujudkan interaksi menerusi komunikasi dialogic turut tidak terkecuali digunakan dalam kandungan web oleh ketiga-tiga universiti tersebut sebagai strategi komunikasi laman sesawang. Komunikasi dialogic ini melibatkan proses perundingan pendapat dan pertukaran idea antara universiti dan khalayak pengguna. Ini bertujuan untuk membantu universiti mewujudkan saluran komunikasi yang efektif disamping membina interaksi secara terus bersama pengguna web. Terdapat dua dimensi yang difokuskan menerusi tema ini iaitu ransangan interaksi bersama key publics dan galakan penglibatan secara bersama antara para pengguna web.

Mengenai ransangan interaksi bersama key publics, terdapat penyediaan saluran komunikasi oleh ketiga-tiga laman sesawang tersebut yang membolehkan para pengguna berhubung secara terus dengan pihak universiti sekiranya ingin mengajukan sebarang pertanyaan dan mencari informasi tertentu. Pada peringkat ini, pihak UM, UPM dan UKM menyediakan saluran dan ruang komunikasi dialogic yang bersifat dua hala dalam kandungan laman sesawang menerusi pautan secara terus dan platform media sosial untuk berinteraksi bersama pengguna. Pautan secara terus ini terdiri daripada penyediaan emel, nombor telefon dan seksyen soalan lazim / frequently asked questions (FAQ) yang berfungsi membantu para pengguna untuk berinteraksi dan menjawab sebarang persoalan yang ingin diutarakan. Ini boleh diperincikan menerusi tangkapan skrin bagi ketiga laman sesawang berikut (lihat Rajah 6):

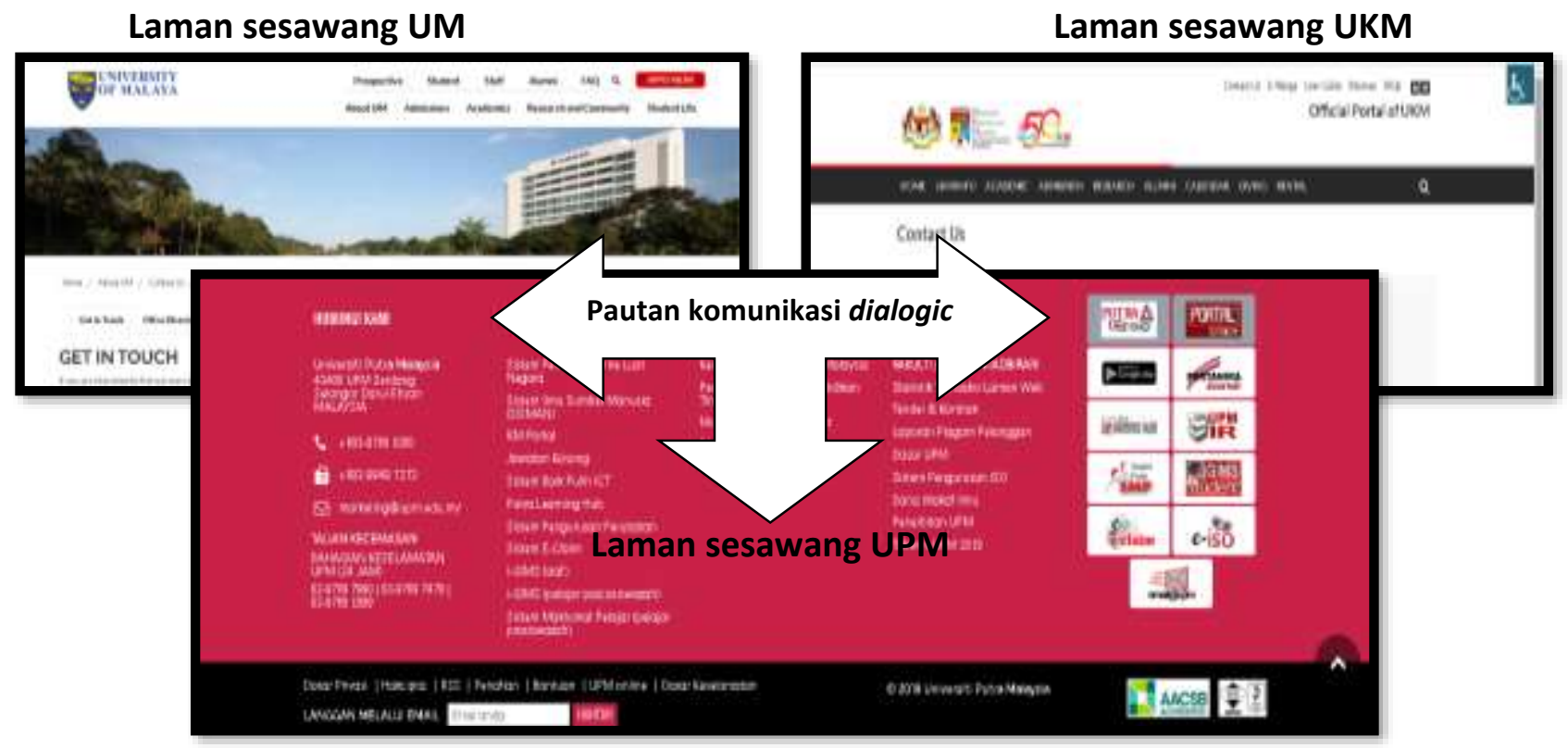

Rajah 6: Pautan komunikasi dialogic dalam portal rasmi universiti (UM, UPM DAN UKM)

Pengaplikasian interaksi menerusi komunikasi dialogic dalam kandungan web turut dilakukan oleh ketiga-tiga universiti menerusi dimensi kedua dengan memberi penekanan terhadap galakan penglibatan secara bersama antara para pengguna web. Ini bertujuan untuk meransang aktiviti komunikasi yang berasaskan word of mouth (WOM) secara dalam talian yang berupaya memberi sebaran informasi secara efektif menerusi rantaian komunikasi yang dibina. WOM ini merupakan praktis komunikasi di mana informasi disebarkan menerusi individu 
disamping membenarkan mereka untuk berkongsi maklumat dan pandangan terhadap sesuatu perkhidmatan atau produk secara bersama. WOM yang bersifat positif mampu mempengaruhi kesedaran, imej, keputusan, dan penilaian seseorang individu.

Dengan itu, pihak UM, UPM dan UKM telah memfokuskan penggunaan media sosial seperti Facebook, Twitter, Instagram dan YouTube sebagai strategi komunikasi laman sesawang untuk membina interaksi secara terus bersama pengguna. Ini dilakukan dengan menyertakan pautan dalam kandungan laman sesawang yang memudahkan para pengguna untuk terus menuju ke halaman aplikasi tersebut. Oleh yang demikian, galakan penglibatan secara bersama para pengguna menerusi media sosial ini mampu bertindak sebagai platform sosial interaksi, komunikasi dan pemasaran kepada universiti. Ini boleh dilihat berdasarkan penyediaan pautan media sosial dalam kandungan web yang disediakan oleh ketiga-tiga universiti tersebut:

\section{Laman sesawang UM}

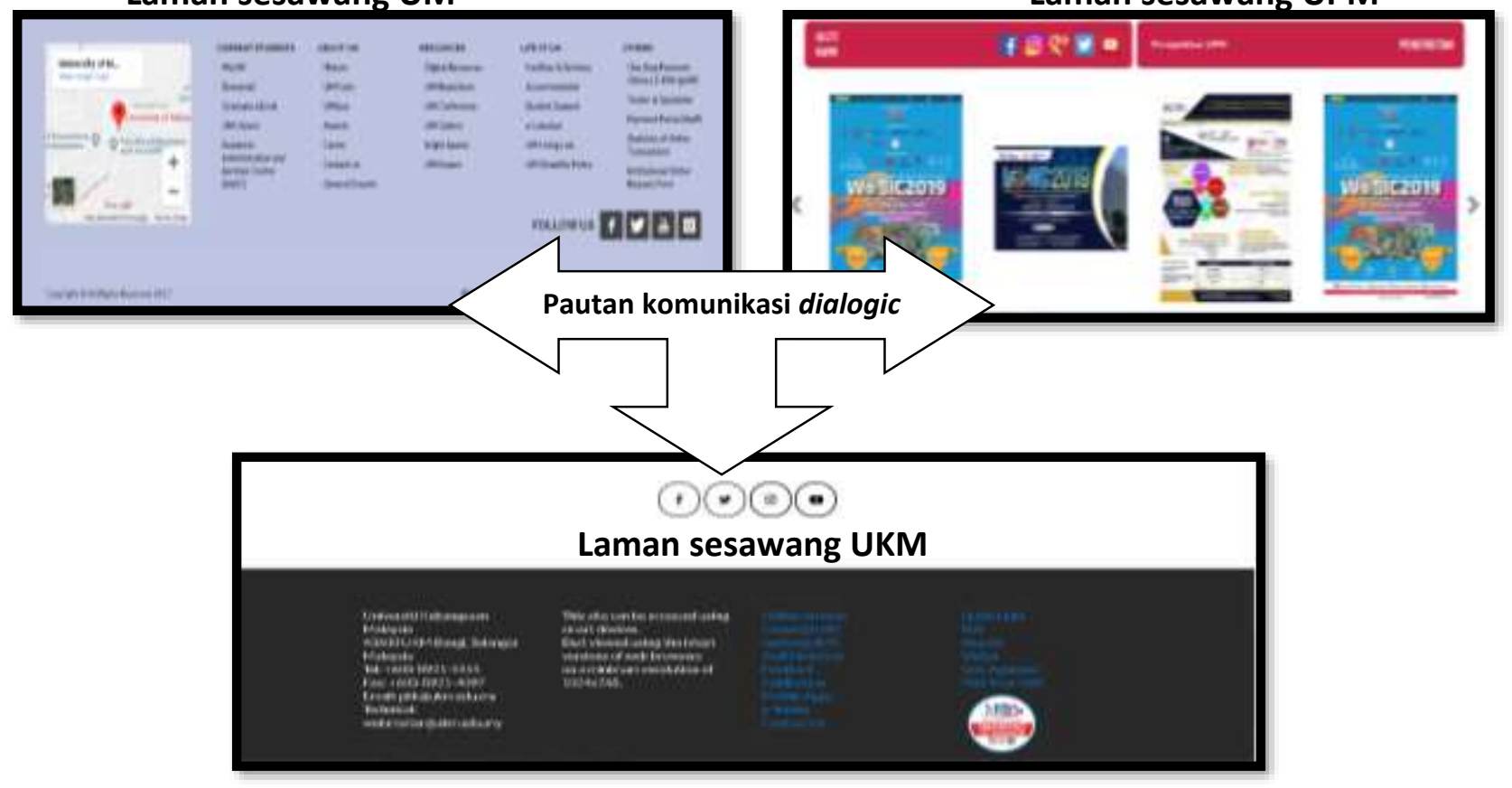

Rajah 7: Pautan media social dalam portal rasmi universiti (UM, UPM dan UKM)

\section{Laman sesawang UPM}

PERBINCANGAN DAN KESIMPULAN KAJIAN

Berdasarkan kajian ini, terdapat tiga tema utama telah dikenalpasti yang menjelaskan secara terperinci peranan kandungan laman sesawang yang bertindak sebagai strategi komunikasi kepada universiti terutama untuk mempromosi dan meningkatkan keterlihatan laman sesawang. Ini merangkumi penekanan terhadap keberkesanan kandungan laman sesawang dalam penyampaian informasi, kelancaran fungsi kebolehgunaan laman sesawang dan mewujudkan interaksi menerusi komunikasi dialogic sebagai strategi ke arah keterlihatan laman sesawang bagi UM, UPM dan UKM. Menerusi ketiga-tiga tema ini juga, kita telah dijelaskan bagaimana sesebuah kandungan laman sesawang itu dirangka bagi tujuan menyebarkan komunikasi secara berkesan, membina interaksi dua hala antara universiti dan khalayak, mempromosi institusi serta meningkatkan keterlihatan laman sesawang. 


\section{a) Penekanan Terhadap Keberkesanan Kandungan Laman Sesawang dalam Penyampaian Informasi}

Menyentuh tema pertama iaitu penekanan terhadap keberkesanan kandungan web dalam penyampaian informasi, terdapat dua dimensi komunikasi yang difokuskan iaitu sebarang informasi secara efektif dan penyediaan pilihan maklumat berasaskan self-selection kepada pengguna laman sesawang. Kedua-dua dimensi ini memberi penerangan mengenai proses penyediaan informasi secara strategik yang diaplikasi dalam kandungan laman sesawang. Secara asasnya, terdapat tiga aspek yang ditumpukan merangkumi penyediaan maklumat mengikut segmen pengguna, jenis informasi yang disediakan dan pembentukan nilai estetika dalam kandungan laman sesawang.

Penyediaan dan penyelarasan maklumat berdasarkan segmen pengguna ini berfungsi untuk memenuhi keperluan informasi kepada khalayak sasaran. Ini disebabkan pengguna laman sesawang terdiri daripada pelbagai segmen dan lapisan masyarakat seperti staf, pelajar, bakal pelajar, bekas pelajar (alumni) serta khayalak umum. Untuk memastikan sebaran komunikasi secara efektif dapat dilakukan, penyediaan informasi dalam kandungan laman sesawang harus dirangka mengikut segmen pengguna agar memudahkan proses penyaluran informasi dilakukan. Ini akan memudahkan khalayak sasaran untuk mencari maklumat yang diperlukan secara tepat dan pantas berdasarkan ruangan segmen pengguna yang disediakan dalam laman sesawang. Pandangan ini juga turut dinyatakan oleh beberapa pengkaji seperti Sharp (2001), Caglar dan Mentes (2012) yang mengakui penyediaan informasi mengikut segmen pengguna membantu dalam mewujudkan sebaran komunikasi laman sesawang yang efektif.

Begitu juga dengan jenis informasi yang disediakan yang turut dikenalpasti menyumbang kepada proses sebaran komunikasi secara efektif kepada pengguna laman sesawang. Penyediaan jenis informasi ini penting kerana bertindak sebagai daya tarikan kepada pengguna laman sesawang untuk melayari sesebuah laman sesawang. Ini kerana menurut Alsudani dan Casey (2009) penggunaan laman sesawang sering kali dikaitkan dengan aktiviti pencarian informasi oleh pengguna laman sesawang. Untuk itu, jenis informasi yang disediakan haruslah bersifat strategik dan berguna kepada khayalak sasaran kerana laman sesawang universiti sering kali menjadi rujukan pertama kepada mereka untuk memperoleh maklumat mengenai institusi. Hal ini turut dinyatakan oleh Stolz et al. (2005) dan Owoyele (2017) mengenai kepentingan penyediaan informasi secara strategik yang boleh menyumbang kepada galakan penggunaan laman sesawang secara berkesan.

Selain memfokuskan penyediaan kandungan laman sesawang mengikut segmen pengguna dan jenis informasi, pembentukan nilai estetika dalam kandungan laman sesawang juga tidak terkecuali berperanan dalam menyumbang kepada sebaran komunikasi secara berkesan. Hal ini disebabkan penggunaan elemen visual dalam komunikasi mampu mewujudkan kesan tersendiri kepada pengguna laman sesawang terutama menyediakan mesej dan informasi yang jelas serta mudah untuk diingati (Bordbar, 2016). Pengaplikasian nilai estetika menerusi gabungan penggunaan imej, grafik dan teks dalam kandungan laman sesawang juga dapat memastikan ketepatan dari segi penyampaian mesej dan mampu mempengaruhi emosi pengguna. Palmer (2002) dan Scott (1999) turut mengakui penyediaan laman sesawang dengan imej dan teks yang menarik berupaya membina sambungan emosi yang kuat kepada khalayak 
web. Oleh yang demikian ini mampu memastikan keberkesanan kandungan laman sesawang dalam menyampaikan informasi dan komunikasi kepada para pengguna laman sesawang.

Berbeza pula dengan dimensi komunikasi kedua iaitu penyediaan pilihan maklumat berasaskan self-selection kepada pengguna laman sesawang. Pengaplikasian self-selection berfungsi untuk memberi kemudahan dari segi akses informasi kepada pengguna laman sesawang. Menerusi self-selection, kandungan laman sesawang dapat diakses mengikut kadar pilihan pengguna dan boleh mengelakkan daripada berlakunya lambakan informasi yang boleh menjejaskan proses sebaran komunikasi. Ini akan memudahkan proses penggunaan bagi tujuan aktiviti pencarian informasi apabila akses kepada maklumat menerusi kandungan laman sesawang dapat dilakukan secara cepat dan pantas. Sebagai contohnya, penyediaan maklumat mengikut segmen pengguna, jenis maklumat dan bahasa (dwibahasa) ini boleh memudahkan proses komunikasi laman sesawang dilakukan secara berkesan. Menurut Youngblood (2013) pengaplikasian fungsi self-selection dalam kandungan laman sesawang tidak hanya dapat memastikan kelancaran dari segi proses penyaluran informasi semata-mata malahan menyumbang kepada kebolehgunaan dan kredibiliti sesebuah laman sesawang.

\section{b) Kelancaran Fungsi Kebolehgunaan Laman sesawang}

Manakala bagi tema dapatan kajian kedua iaitu kelancaran fungsi kebolehgunaan laman sesawang telah menjelaskan secara terperinci bagaimana aspek reka bentuk berupaya mempengaruhi proses sebaran komunikasi secara efektif kepada pengguna laman sesawang. Berdasarkan tema ini terdapat dua dimensi yang telah dikenalpasti menyumbang kepada fungsi kelancaran kebolehgunaan iaitu penekanan terhadap elemen mesra pengguna (user-friendly) dalam mengemudi laman sesawang dan susun atur informasi yang sistematik diaplikasi dalam kandungan laman sesawang. Kelancaran fungsi kebolehgunaan ini penting kepada pengguna agar mereka dapat menikmati web controllability dan web efficiency ketika mengakses kandungan laman sesawang (Mohd Azul et al., 2016). Ini memberi kebebasan kepada para pengguna untuk mengemudi laman sesawang secara mudah dan melakukan aktiviti yang diingini. Braddy et al. (2003) serta Youngblood (2013) berpendapat kelancaran dalam pengemudian laman sesawang ini berupaya memberi pengalaman positif daripada segi aktiviti laman sesawang kepada pengguna menerusi kemudahan dan kelancaran dari segi akses maklumat dalam kandungan laman sesawang.

Begitu juga dengan peranan dimensi kedua iaitu susun atur informasi yang sistematik untuk meningkatkan fungsi kebolehupayaan sesebuah kandungan laman sesawang. Susun atur informasi yang dirangka secara efektif berupaya meningkatkan kecekapan daripada segi penggunaan yang mana turut membantu pengguna laman sesawang untuk mengakses kandungan laman sesawang dalam tempoh yang singkat dan efisyen (Alsudani \& Casey, 2009). Ini penting untuk membantu para pengguna laman sesawang mencapai matlamat penggunaan terutama ketika melayari laman sesawang. Tanpa susun atur informasi yang sistematik dalam kandungan laman sesawang boleh menganggu proses penyebaran informasi dan komunikasi secara berkesan. Perlu difahami keberkesanan penyampaian komunikasi dalam bentuk paparan ini bergantung kepada sejauh mana susun atur dalam kandungan laman sesawang itu dirangka secara efektif (Sharp, 2001). Justeru itu, terdapat kepentingan untuk merangka kandungan laman sesawang yang mempunyai susun atur yang sistematik dan strategik agar dapat memberikan 
pengalaman terhadap kecekapan laman sesawang yang tinggi kepada pengguna di mana akhirnya boleh menyumbang kepada komunikasi laman sesawang yang efektif.

\section{c) Mewujudkan Interaksi Menerusi Komunikasi Dialogic}

Seterusnya tema dapatan kajian ketiga iaitu mewujudkan interaksi menerusi komunikasi dialogic pula memberi penerangan secara terperinci mengenai penyediaan saluran komunikasi dalam kandungan laman sesawang yang berfungsi untuk membina interaksi secara terus bersama pengguna laman sesawang. Komunikasi dialogic ini berfungsi menggalakkan proses perundingan pendapat dan pertukaran idea bersama pengguna. Terdapat dua dimensi komunikasi yang dikenalpasti menerusi tema ini iaitu rangsangan interaksi bersama key publics dan galakan penglibatan secara bersama antara para pengguna laman sesawang. Rangsangan interaksi bersama key publics ini bertujuan untuk mewujudkan saluran komunikasi yang efektif di samping membina interaksi secara bersama dengan para pengguna. Menerusi rangsangan interaksi ini juga, pihak universiti mampu membina hubungan komunikasi yang positif bersama pengguna dan ini boleh mempengaruhi sebaran komunikasi secara berkesan kepada mereka. Pandangan ini juga dinyatakan oleh beberapa pengkaji seperti Kent dan Taylor (1998), Seltzer dan Mitrook (2007), Bortree dan Seltzer (2009), dan Rybalko dan Seltzer (2010) yang menemukan fungsi komunikasi dialogic dalam membina hubungan komunikasi yang positif secara dalam talian.

Interaksi menerusi komunikasi dialogic turut tidak terkecuali diimplementasi dengan memberi penekanan terhadap galakan penglibatan secara bersama menerusi kandungan laman sesawang yang disediakan. Ini boleh dilakukan menerusi penggunaan media sosial seperti Facebook, Twitter, Instagram dan YouTube sebagai strategi untuk membina interaksi secara berkesan bersama pengguna. Hal ini bagi mewujudkan aktiviti komunikasi yang berasaskan word of mouth (WOM) secara dalam talian. Dengan mewujudkan WOM yang bersifat positif, pihak universiti mampu mempengaruhi kesedaran, imej, keputusan, dan penilaian pengguna laman sesawang. Ini turut diakui oleh pengkaji seperti Kelleher (2009), Yang et al. (2010) dan Syed Jamal et al. (2019) menemukan peranan komunikasi dialogic sebagai strategi komunikasi laman sesawang yang berupaya membina hubungan komunikasi yang positif bersama pengguna secara dalam talian. Oleh itu, penglibatan secara bersama antara universiti dan para pengguna melalui media sosial ini mampu bertindak sebagai platform sosial interaksi, komunikasi dan pemasaran kepada universiti.

Menerusi perbincangan terhadap tiga tema utama ini kita dapat mengenal pasti elemen penting yang menyumbang kepada keberkesanan penyampaian komunikasi menerusi analisis terhadap penggunaan laman sesawang oleh ketiga-ketiga universiti tersebut. Pengimplementasian tiga elemen yang berfokus kepada kandungan (content), kebolehgunaan (usability) dan mewujudkan komunikasi dialogic telah menjadi strategi utama kepada ketiga-tiga universiti tersebut untuk mewujudkan sebaran komunikasi laman sesawang secara berkesan. Untuk itu kita dapat melihat bagaimana penekanan diberikan terhadap kemudahan pengemudian (navigate), mewujudkan interaktiviti, menjamin keselamatan data, penerapan nilai estetika dan membentuk kandungan yang bersifat informatif oleh ketiga-tiga laman sesawang universiti tersebut. Hal ini bagi meningkatkan keberkesanan komunikasi laman sesawang agar para pengguna dapat menikmati pengalaman positif ketika melayarinya. Ini akhirnya boleh menyumbang kepada daya tarikan kepada khalayak sasaran dan capaian impak positif kepada 
universiti. Sebagai contohnya boleh membantu dari segi mempromosi dan meningkatkan keterlihatan universiti secara dalam talian menerusi keberkesanan komunikasi dan jalinan perhubungan yang rapat dengan khalayak sasaran. Dalam kata lain, dengan penghasilan kandungan laman sesawang yang berkualiti ini dapat menyumbang ke arah positive response action (PRA) kepada pengguna laman sesawang yang akhirnya memberi implikasi positif dalam mempromosi dan meningkat keterlihatan laman sesawang kepada universiti. Oleh itu, penting bagi universiti ataupun organisasi lain memberi perhatian sewajarnya terhadap perangkaan dan penggunaan kandungan laman sesawang menerusi pemfokusan terhadap tiga elemen yang telah dinyatakan bagi menyumbang kepada keberkesanan penggunaannya yang akhirnya membantu dalam merealisasikan misi dan matlamat yang ingin dicapai.

\section{BIODATA}

Muhammad Zaiamri bin Zainal Abidin merupakan pelajar Doktor Falsafah di Jabatan Pengajian Media dan Komunikasi, Fakulti Sastera dan Sains Sosial, Universiti Malaya. Beliau mempunyai pengalaman luas dalam bidang penyelidikan, antaranya ialah Malaysian Elders Longitudinal Research (High Impact Research, Universiti Malaya) dan Penggunaan Kandungan Media dan Pembentukan Idea Melayu dalam Kalangan Belia di Malaysia (Pusat Kajian dan Kecemerlangan Melayu).E-mel: zaiamrizainal@um.edu.my/zaiamrizainal@gmail.com

Amira Firdaus adalah Pensyarah Kanan di Jabatan Pengajian Media dan Komunikasi, Fakulti Sastera dan Sains Sosial, Universiti Malaya. Berkelulusan Doktor Falsafah dari University of Melbourne. Kepakaran akademik beliau merangkumi bidang komunikasi organisasi, kewartawanan dan penggunaan media baharu. E-mel: amira_firdaus@um.edu.my

Md Azalanshah Md Syed adalah Pensyarah dan Ketua Jabatan di Jabatan Pengajian Media dan Komunikasi, Fakulti Sastera dan Sains Sosial, Universiti Malaya. Beliau berkelulusan Sarjana dalam bidang Produksi Skrin (Flinders University) dan PhD (Royal Melbourne Institute of Technology) dalam bidang media dan komunikasi. E-mel: azalan@um.edu.my 


\section{RUJUKAN}

Abedin, B., \& Sohrabi, B. (2009). Graph theory application and web page ranking for website link structure improvement. Behavior \& Information Technology, 2(1), 63-72.

Acosta-Vargas, P., Ramos-Galarza, C., Salvador-Ullauri, L., Chanchí, G. E., \& Jadán-Guerrero, J. (2020, July). Improve accessibility and visibility of selected university websites. Paper presented at International Conference on Applied Human Factors and Ergonomics (pp. 229-235). Cham.: Springer.

Aguillo, I. (2009). Measuring the institutions' footprints in the web. Library High Tech, 27(4), 540556.

Aguillo. (2010, March). Web, webometrics and the ranking of universities. Proceedings of the 3rd European Network of Indicators Designers Conference on STI Indicators for Policymaking and strategic decision, CNAM, Paris (to appear, 2010).

Alsudani, F., \& Casey, M. (2009, September). The effect of aesthetics on web credibility. Proceedings of the 23rd British $\mathrm{HCl}$ Group Annual Conference on People and Computers: Celebrating People and Technology (pp. 512-519).

Aoki, K. (2000). Taxonomy of interactivity on the web. Retrieved from http://citeseerx.ist.psu.edu/viewdoc/citations?doi=10.1.1.198.4493

Ashraf, N., Faisal, M. N., Jabbar, S., \& Habib, M. A. (2019). The role of website design artifacts on consumer attitude and behavioral intentions in online shopping. Technical Journal, 24(02), 50-60.

Avila, E. N. (1997). Connecting online - Creating a successful image on the Internet. The Oasis Press (p. 31).

Barjak, F., Li, X., \& Thelwall, M. (2007). Which factors explain the web impact of scientists' personal homepages? Journal of the American Society for Information Science and Technology, 58(2), 200-211. https://doi.org/10.1002/asi.20476

Barnett, G. A., \& Park, H. W. (2005, October). The structure of international internet hyperlinks and bilateral bandwidth. Annales des telecommunications, 60(9-10), 1110-1127.

Bortree, D. S., \& Seltzer, T. (2009). Dialogic strategies and outcomes: An analysis of environmental advocacy groups' Facebook profiles. Public Relations Review, 35(3), 317-319.

Braddy, P. W., Thompson, L. F., Wuensch, K. L., \& Grossnickle, W. F. (2003). Internet recruiting: The effects of web page design features. Social Science Computer Review, 21(3), 374-385.

Brown, J., \& Oplatka, I. (2006). Universities in a competitive global marketplace: A systematic review of the literature on higher education marketing. International Journal of Public Sector Management, 19(4), 316-338.

Caglar, E., \& Mentes, S. A. (2012). The usability of university websites: A study on European University of Lefke. International Journal of Business Information Systems, 9, 9-10.

Chevalier, K., Bothorel, C., \& Corruble, V. (2003, October). Discovering rich navigation patterns on a web site. Paper presented at International Conference on Discovery Science (pp. 6275). Springer, Berlin, Heidelberg.

Chung, C. J., \& Park, H. W. (2012). Keterlihatan laman sesawang of scholars in media and communication journals. Scientometrics, 93, 207-215. 
Conte, T., Massollar, J., Mendes, E., \& Travassos, G. H. (2007, September). Usability evaluation based on web design perspectives. First International Symposium on Empirical Software Engineering and Measurement (ESEM 2007), Madrid, 2007, (pp. 146-155).

Cormier, K. (1999). Developing a website. TMA Journal, 19(2).

De Filippo, D., Casani, F., Garcia-Zorita, C., Efrain-Garcia, P., \& Sanz-Casado, E. (2012). Visibility in international rankings: Strategies for enhancing the competitiveness of Spanish universities. Scientometrics, 93, 949-966.

Dumont, K., \& Frindte, W. (2005). Content analysis of the homepages of academic psychologists. Computers in Human Behaviour, 21(1), 73-83.

Fatta, D. D., Caputo, F., Evangelista, F., \& Dominici, G. (2016). Small world theory and the world wide web: Linking small world properties and website centrality. International Journal of Markets and Business Systems, 2(2), 126-140.

Habee Bullah Affandy, Azham Hussain, \& Maslinda Mohd Nadzir. (2017). Balancing usability and aesthetic elements in universities' website: A systematic review. Jurnal Komunikasi: Malaysian Journal of Communication, 33(4), 190 - 203.

Herring, S. C. (2009). Web content analysis: Expanding the paradigm. In Hunsinger J., Klastrup L., Allen M. (Eds.), International handbook of internet research. Dordrecht: Springer.

Huertas, A., Rovira, C., \& Fernández-Cavia, J. (2011). Interactivity as a key factor in city website visibility and place brand communication. Journal of Town \& City Management, 2(2), 132142.

Jeyshankar, R. (2019). Webometric analysis of deemed university websites in India. Library Philosophy and Practice (e-journal), 2266. Retrieved from https://digitalcommons.unl.edu/libphilprac/2266/

Jeyshankar, R., \& Babu, B. R. (2009). Websites of universities in Tamil Nadu: A webometric study. Computer Science, 56(2), 69-79.

Kelleher, T. (2009). Conversational voice, communicated commitment, and public relations outcomes in interactive online communication. Journal of Communication, 59(1), 172188.

Kent, M. L., \& Taylor, M. (1998). Building dialogic relationships through the world wide web. Public Relations Review, 24(3), 321-334.

Kim, Y. H., \& Kim, H. H. (2008). Development and validation of evaluation indicators for a consortium of institutional repositories: A case study of dcollection. Journal of the American Society for Information Science and Technology, 59(8), 1282-1294.

Leavitt, M. O., \& Shneiderman, B. (2006). Research - Based web design and usability guidelines. Washington: U.S. General Services Administration.

Lee, M., \& Park, H.W. (2012). Exploring the keterlihatan laman sesawang of world-class universities. Scientometrics, 90(1), 201-218.

Masterson, K. (2011, January 30). Can new online rankings really measure colleges' brand strength? Unlikely, experts say. Chronicle of Higher Education. Retrieved from http://chronicle.com/article/Can-New-Online-Rankings-Really/126083/

Matei, S. A. (2006). Globalization and heterogenization: Cultural and civilizational clustering in telecommunicate space (1989-1999). Telematics and Informatics, 23(4), 316-331. 
Matusitz, J. (2005). Deception in the virtual world: A semiotic analysis of identity. Journal of New Media and Culture, 3(1), 54-63.

McMillan, S. J. (2000). The microscope and the moving target: The challenge of applying content analysis to the world wide web. Journalism and Mass Communication Quarterly, 77(1), 80-98.

McNutt, K., \& Marchildon, G. (2009). Think tanks and the web: Measuring visibility and influence. Canadian Public Policy, 35(2), 219-236.

Meho, L. I., \& Yang, K. (2007). Impact of data sources on citation counts and rankings of LIS faculty: Web of Science versus Scopus and Google Scholar. Journal of the American Society for Information Science and Technology, 58(3), 2105-2125.

Mirica, A., \& Toma, I. E. (2018, July). Keterlihatan laman sesawang of romanian universities: An analysis based on website analytics and social media data. Paper presentation at 4th International Conference on Higher Education Advances (HEAd'18), Universitat Polit’ecnica de Val’encia, Val’encia. http://dx.doi.org/10.4995/HEAd18.2018.8036

Mohd Azul Mohamad Salleh, Ali Salman, Mohd Nor Shahizan Ali, \& Hasrul Hashim. (2016). The importance of usability features in enhancing online communication satisfaction. Jurnal Komunikasi: Malaysian Journal of Communication, 32(1), 1-15.

Monge, P. R., Contractor, N. S., Peter, R., Contractor, P. S., \& Noshir, S. (2003). Theories of communication networks. USA: Oxford University Press.

Moslehifar, M. A., Ibrahim, N. A., \& Sandaran, S. C. (2016). Assessing the quality of trust features on website content of top hospitals for medical tourism consumers. Jurnal Komunikasi: Malaysian Journal of Communication, 32(2), 472-493.

$\mathrm{Ng}, \mathrm{W}$. S. (2020). Enhancing the quality of educational website design through assessment for learning strategies. In Information Resources Management Association (Ed.), Learning and performance assessment: Concepts, methodologies, tools, and applications (pp. 1106-1133). USA: IGI Global.

Ojugo, A., \& Otakore, D. (2018). Redesigning academic website for better visibility and footprint: A case of the federal university of petroleum resources effurun website. Network and Communication Technologies, 3(1), 33-44.

Owoyele, S. (2017). Website as a marketing communication tool (Tesis Sarjana Yang Tidak Diterbitkan, Centeria University of Applied Sciences, Kokkola, Finland).

Padmannavar, S., \& Joshi, J. (2011). A survey analysis of national and international university web sites contents. International Journal of Computer Application, 33(6), 49-58.

Palmer, O. (2002). Web site usability, design, and performance metrics. Journal of Information Systems Research, 13(2), 151-167.

Park, H. W., \& Thelwall, M. (2006). Web-science communication in the age of globalization. New Media \& Society, 8(4), 629-650.

Petricek, V., Escher, T., Cox, I. J., \& Margetts, H. (2006, May). The web structure of e-government: Developing a methodology for quantitative evaluation. Proceedings of the 15th International Conference on World Wide Web (pp. 669-678).

Poock, E. (2006). Characteristics of an effective web site in educational leadership. College Student Journal, 40(4), 785-790. 
Qiu, M. (2020). The influence of culture on corporate website design (Dissertation Master, Department of Informatics and Media, Faculty of Social Sciences, Disciplinary Domain of Humanities and Social Sciences, Uppsala University, Sweeden). Retrieved from urn:nbn:se:uu:diva-414050

Rybalko, S., \& Seltzer, T. (2010). Dialogic communication in 140 characters or less: How fortune 500 companies engage stakeholders using Twitter. Public Relations Review, 36(4), 336341.

Scott, S. V. (1999). The academic as service provider: Is the customer 'always right?. Journal of Higher Education Policy and Management, 21(2), 193-202.

Seltzer, T., \& Mitrook, M. A. (2007). The dialogic potential of weblogs in relationship building. Public Relations Review, 33(2), 227-229.

Shahruddin, S. S., Chik, R. Z. W., \& Malik, I. S. A. (2019, April). Visibility study in strategizing for web marketing and webometric university ranking in Malaysia. Journal of Physics: Conference Series, 1193(1), p.012002.

Sharp, L. (2001). Positive response action: The ultimate goal of website communication. Emerald Insight, 6(1), 41-52.

Sheehan, B., \& Doherty, C. (2004) Re-weaving the Web: Integrating print and online communications. Journal of Interactive Marketing, 15(2), 117-124.

Stolz, C., Viermetz, M., Skubacz, M., \& Neuneier, R. (2005). Guidance performance indicator web metrics for information driven web sites. Paper presented at IEEE/WIC/ACM International Conference on Web Intelligence 2005 (pp. 186-192).

Suksida, T., \& Santiworarak, L. (2017). A study of website visibility in webometrics ranking of world university by using seo tool case study of Thailand Rajabhat University. Proceedings of the 6th International Conference on Language, Education, Humanities and Innovation (pp. 135-142). Reading, Singapore: The Interdisciplinary Circle of Science, Arts and Innovation (ICSAI).

Syed Jamal Abdul Nasir Syed Mohamad, Roshidi Hassan, Norlida Abdul Hamid, \& Ahmad Syahmi Ahmad Fadzil. (2019). Developing measures of dialogic communication on organizational change: An exploratory study. International Journal of Academic Research in Business and Social Sciences, 9(6), 640-652. http://dx.doi.org/10.6007/IJARBSS/v9-i6/5978

Tarafdar, M. (2005). Analyzing the influence of website design parameters on website usability. Information Resources Management Journal (IRMJ), 18(4), 62-80.

Thelwall, M. (2002). Conceptualizing documentation on the web: An evaluation of different heuristic-based models for counting links between university web sites. Journal of the American Society for Information Science and Technology, 53(12), 995-1005.

Viloria, A., Torres, M., Vásquez, C., Varela, N., Cabrera, D., \& Gaitan-Angulo, M. (2016). Ranking of scientific visibility of Latin American universities. International Journal of Control Theory and Applications, 9(44), 409-414.

Wallerstein, I. (1974). Dependence in an interdependent world: the limited possibilities of transformation within the capitalist world economy. African Studies Review, 1-26.

Webometric. (2020, February 2). ranking of web universities. Diperoleh daripada https://www.webometrics.info/en/WORLD 
Weideman, M. (2009). Website visibility: The theory and practice of improving rankings. Oxford: Chandos.

Wirtz, J. G., \& Zimbres, T. M. (2018). A systematic analysis of research applying 'principles of dialogic communication' to organizational websites, blogs, and social media: Implications for theory and practice. Journal of Public Relations Research, 30(1-2), 2-34.

Xia, J., \& Sun, L. (2006). Factors to assess self-archiving in institutional repositories. Serials Review, 33(2), $73-80$.

Yang, S. U., Kang, M., \& Johnson, P. (2010). Effects of narratives, openness to dialogic communication, and credibility on engagement in crisis communication through organizational blogs. Communication Research, 37(4), 473-497.

Youngblood, N. E. (2010). Integrating usability and accessibility into the interactive media and communication curriculum. Global Media Journal, 9(17), 1-37.

Yusof, U. K., Khaw, L. K., Ch'ng, H. Y., \& Neow, B. J. (2010, June). Balancing between usability and aesthetics of web design. Paper presented at 2010 International Symposium on Information Technology, Kuala Lumpur, Malaysia (Vol. 1, pp. 1-6).

Zhang, P., Dran, G. V., Blake, P., \& Pipithsuksunt, V. (2000). A comparison of the most important website features in different domains: An empirical study of user perceptions. Proceedings of Americas Conference on Information Systems AMCIS 2000, 41, 1367-1372. Retrieved from http://aisel.aisnet.org/amcis2000 